\title{
非プロトン溶媒中における 1-(p-ニトロフェニル)-2-(2-
}

\section{および4-キノリル)エチル=アセタートのカルボン酸 \\ 触媒による脱離反応}

一一溶媒効果, 反応速度比, 塩類効果, $\beta$-水素同位体効果 -

（1975年 2 月 7 日受理）

平田博文* . 田中洋**. 福住一雄**

1-(p-ニトロフェニル)-2-(2-および 4-キノリル)エチル=アセタート（[1 a おおよび [1 b]) からカ ルボン酸触媒によってそれぞれ trans-2-および 4-(p-ニトロスチリル)キノリン([2a]および $[2 \mathrm{~b}])$ を生成する脱離反応を若干の非プロトン溶媒を用いて速度論的に研究した。脱離速度はカルボン酸の初 濃度に一次で比例し，反応全体として一般酸触媒で起こった。ジメチルスルホキシド・水 $(22: 1 \mathrm{v} / \mathrm{v})$ 中, $90^{\circ} \mathrm{C}$ に批けるアセタートアニオン ( $\left.\mathrm{AcOM}, \mathrm{M}=\mathrm{Na}, \mathrm{Li}\right)$ による[1]の脱離は酢酸触媒の場合 上りも遅く，その速度は $[\mathrm{AcOM}]_{0}^{1 / 2}$ に比例した。溶媒効果（[1 a 反応速度比 $r=k([1 \mathrm{a}]) / k([1 \mathrm{~b}])$ ，ジメチルスルホキシド・水 $(22: 1 \mathrm{v} / \mathrm{v})$ 中, $90^{\circ} \mathrm{C}$ での酢酸触媒 飞よる脱離反麻の塩類効果, [1 a ] $\beta \beta$-水素同位体効果 $\left(k_{\mathrm{H}} / k_{\mathrm{D}}>1\right.$, 酶酸エチル中, $\left.50^{\circ} \mathrm{C}\right)$ より, カル ボン酸が [1]のキノリン空素にプロトン化して緊密イオン対 [5]を生じ,〔5]の一部が溶媒分子女 反応（相互作用）して溶媒介在イオン対 [6] を生成し，このイオン対 [5]および [6]の対陰イオ ソ，カルボキシラートアニオンがそれぞれの $\beta$-水素を律速的に攻撃して生成物 [2]を生ずる機構を 考えた。また，カルボキシラートフニオンがキノリニウム環平面上に位鹰するイオン対モデルを仮定し て得られた実験結果を説明した。及一氷素同位体効果から，触媒のカルボン酸が酢酸からトリクロロ酥酸 ヘと变化するにつれて反応の僄移状態が近 $\mathrm{E} 1 \mathrm{cB}$ 型から理想型を経て近 $\mathrm{E} 1$ 型に移行することがわ かった。

\section{1 緒富}

炭素酸の岸素-水亲結合は塩基触媒の存在下でプロトンが引き 抜かれカルバニオンを生し，縮合や交換反応を起こす。2-和よび 4-アルキルピリジンやアルキルキノリンの $\alpha$-位のプロトンは臺 素原子の電子吸引性および共鳴安定性のため弱い酸性を示し, 強 い塩基の存在下でカルバニオンを生じ，カルボニル化合物との縮 合1) H-D（あるいはT）交換2 が起こる。また，ピこリンの側 鎖メチル基のブロトン性金属ナトリウムやカリウムタ) あるい性り チウム(フェニルリチウムとしで方)と交換が起こることる知られ

* 工羓技術院果京工業試験所, 151 東京都橴谷区本町

** 名古堂大学工学部応用化学教室, 464 名古菿市千種区不 老町

1) L. A. Paquette, "Principles of Modern Heterocyclic Chemistry", W. A. Benjamin Inc, New York, N. Y. (1968) p. 245, 293.

2) W. N. White, D. Lazine, J. Org. Chem., 34, 2756 (1969) ; A. I. Shatenshtein, Advans. Phys. Org. Chem., 1, 169(1963) ; 川添 豊, 前田満和, “へテロ環の化学”, 南江堂 (1970) 第 2 集, p. 39.

3) N. E. Sartoris, H. Pines, J. Org. Chem., 34, 2113, 2119 (1969).
ている。このようにピリジンやキノリン環など芳香環の骨格に窒 素原子をるつアザアリール化合物の睢鎖のブロトンが酸性である ことから，アザアリール基を電子吸引基にすつ化合物の脱離反応 は十分可能である。

著者は既報ら)で 1-(p-ニトロフェニル)-2-(2-キノリル)エチル= アセタート[1 a $]$ の脱離がカルボン酸触媒存在下で容易に起こり, ヘンゼン溶媒中, $40^{\circ} \mathrm{C}$ での速度諭的研究から，カルボン酸のキ ノリン窒索へのプロトン化, カルボキシラートアニオンの $\beta$-水 秦攻撃で反応が起こることを報告した。本報では，酸素や窒素原 子をるつ非ブロトン溶媒を用いてその溶媒効果を調べるとともに，

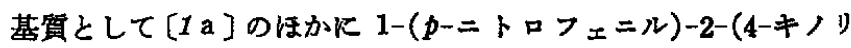
ル)エチルンアセタート $[1 \mathrm{~b}]$ を用いてその反応珄の違い（反応速 度比), 塩類効果について検討し, さらに $\beta$-水素同位体効果上り 反応の遷移状態について検討した。

4) V. Boekelheide, H. Fritz, J. M. Ross, H. X. Haempfen, Tetrahedron, 20, 33(1964).

5）平田博文, 福生一雄, 日化, 1974, 1929. 


\section{2 实験}

\section{1 溶媒および原料}

実験代用いた 8 種の溶媒（アニソール，ジオキサン,アセトニ トリル, ジメチルスルホキシド， $N, N$-ジメチルホルムアミド, アセトフェノン, 酢酸エチル, シクロヘキサノン) は常法け飞し たがってて精媻，蒸留して使用した。カルボン酸およびピリジン，

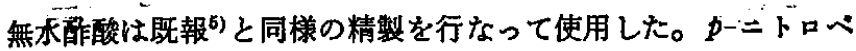
ンズアルデヒドは文献りにしたがって合成した。 $\mathrm{mp} 106^{\circ} \mathrm{C}$ ，キナ ルシシン，レピジンは市眅特級試薬を，重水は Merck (99.75\%) を使用した。酶酸ナトリウム，眽酸リチウム，過塩素酸リヂヴム 恃市肘品を適当な温度で十分乾蜗したるのを使用した。

\section{2 生 成 物}

2.2.1 1-(p-ニトロフェニル)-2-(2-キノリル)エチル=アセタ 一ト 1 a $]$ : 既報可飞したがって合成した。収率 70 80\%，mp $76 \sim 78^{\circ} \mathrm{C}$ 。

2.2.2 1-(p-ニトロフェニル)-2-(4-キノリル)エタノール：文 献りにしたがって合成した。収率 $24 \sim 40 \%, \mathrm{mp} 188 \sim 189^{\circ} \mathrm{C}$ (文 献値 $\left.\left.{ }^{8}\right) 187 \sim 188^{\circ} \mathrm{C}\right), \mathrm{IR}(\mathrm{KBr}): 3200(\mathrm{OH}) \mathrm{cm}^{-1}, m / e 294(\mathrm{M})$, $276\left(\mathrm{M}-\mathrm{H}_{2} \mathrm{O}\right), 143\left(\mathrm{P} ; \mathrm{C}_{10} \mathrm{H}_{9} \mathrm{~N}\right)$ 。

2.2.3 1-(p-ニトロフェニル)-2-(4-キ/リル) エチル=アセタ 一ト [1 b $]:[1 \mathrm{a}]$ と同じ方法5) で合成した。取率 60〜80\%，

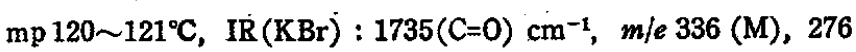
$\left(\mathrm{M}-\mathrm{CH}_{8} \mathrm{CO}_{2} \mathrm{H}\right), 143\left(\mathrm{P} ; \mathrm{C}_{10} \mathrm{H}_{9} \mathrm{~N}\right), 43\left(\mathrm{COCH}_{3}\right)_{\circ}$

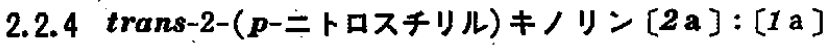
$250 \mathrm{mg}$, 酶酸 $1 \mathrm{~m} l$ を酷酸エチル $(20 \mathrm{~m} l)$ 中で 3 時間還流後, 反応液を室温で放四すると黄色の結晶が析出した。結晶が析出し ないときは，溶媒を少量除去すると結晶が析出する。この結晶を

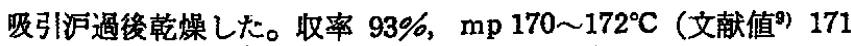
$\sim 172^{\circ} \mathrm{C}$ ), IR $(\mathrm{KBr}): 960 \sim 970$ (trans $-\mathrm{CH}=\mathrm{CH}$ ) $\mathrm{cm}^{-1}$, UV $: \lambda_{\max }$ $367 \mathrm{~nm}, \log \varepsilon 4.67\left(0.1 \mathrm{~mol} / l \mathrm{HCl} / \mathrm{C}_{2} \mathrm{H}_{6} \mathrm{OH}\right), \lambda_{\max } 367 \mathrm{~nm}, \log \varepsilon$ $4.66\left(0.1 \mathrm{~mol} / l \mathrm{HCl} / 90 \% \mathrm{CH}_{3} \mathrm{OH}-10 \% \mathrm{H}_{2} \mathrm{O} \mathrm{v} / \mathrm{v}\right)$ 。

2.2 .5 trans-4-(p-ニトロスチリル) キ ノリン $[2 \mathrm{~b}]:[1 \mathrm{~b}]$ $250 \mathrm{mg}$ ，酢酸 $1 \mathrm{~m} l$ をアセトニトリル $(20 \mathrm{~m} l)$ 中で 3 時間薑流

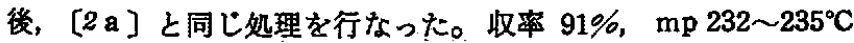
(文献値 ${ }^{8)}$ 227 $229^{\circ} \mathrm{C}$ ), IR ( $\mathrm{KBr}$ ) : 960 970 (trans- $\mathrm{CH}=\mathrm{CH}-$ ) $\mathrm{cm}^{-1}$, UV : $\lambda_{\max } 370 \mathrm{~nm}, \log \varepsilon 4.47\left(0.1 \mathrm{~mol} / l \mathrm{HCl} / \mathrm{C}_{2} \mathrm{H}_{5} \mathrm{OH}\right)$, $\lambda_{\max } 370 \mathrm{~nm}, \log \varepsilon 4.43\left(0.1 \mathrm{~mol} / l \mathrm{HCl} / 90 \% \mathrm{CH}_{8} \mathrm{OH}-10 \% \quad \mathrm{H}_{2} \mathrm{O}\right.$ $\mathrm{v} / \mathrm{v})_{0}$

2.2 .6 キナルジンー $d_{8}:$ キナルジン $(0.5 \mathrm{~m} l)$, 水酸化カリウ $A(0.03 \mathrm{~g})$, 重水 $(1 \mathrm{ml})$ の混合物をパイレックス封管中, 180 ${ }^{\circ} \mathrm{C}$ で 8 時間反応後，四塩化炭素 $(2 \mathrm{~m} l)$ で抽出し，少量の水で

6) J. A. Riddick, W. B. Bunger, “Organic Solvents”, 3 rd Ed., Wiley-Interscience; New York; London-Sydney. Toronto (1970) Chapter N, p. 552 ; 畑 一夫, 杉山 登, 小林貞之助, 大田正樹, 大本道則編、“化学実験法”，東京 化学同人 (1960) 第 1 章, p. 11.

7)- S. U. Liebeman; R. Cormor, “Organic Syntheses", John Wieley \& Sons Inc., New York, N. Y. (1943) Coll. Vol. II, p. 441.

8) R.S. Tipson, A. F. Walter, J. Amer. Chem. Soc., 70, 892(1948).

9) A.F. Walter, R. S. Tipson, L. H. Cretcher, ibid., 67, 1501 (1945).
洗浄, 無水硫酸ナトリウムで乾蜗後溶媒を除去した。全体の重水 慗化率は 74〜75\% たった（NMRで定量。

2.2 .7 1-(p-ニトロフェニル)-2-(2-キノリル)エタンール-2,

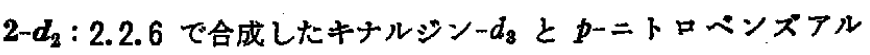
デヒドとの混合物 (1:1) を $\mathrm{CCl}_{4}+\mathrm{C}_{2} \mathrm{D}_{6} \mathrm{OD}(1: 1 \mathrm{v} / \mathrm{v})$ 溶某中 で 48 時間還流後, 反応液を室温で放置すると淡黄色の結晶が析 出した。この結晶を吸引沪過後彰燥してつぎの合成に用いた。収 率 $40 \%, \mathrm{mp} 159 \sim 161^{\circ} \mathrm{C}$ 。

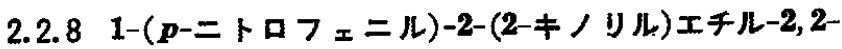
$d_{2}=$ アセタート $\left[I \mathbf{a}-d_{2}\right]: 2.2 .7$ で合成した重水素化アルコール を[1 a ]と同じ方法りでステル化した。収率 70\%， mp 71〜72 ${ }^{\circ} \mathrm{C}, \operatorname{IR}(\mathrm{KBr}): 1735(\mathrm{C}=0) \mathrm{cm}^{-1}$; 重办素の含量 : 全体で 90〜92 $\%$ (NMR 加 5 定量)， $d_{2} 92 \% ， d_{1} 6 \% ， d_{0} \%$ (MS 加定量)。

2.2.9 trans-2-(p-ニトロスチリル)キノリン- $\beta-d\left[2 \mathrm{a}-d_{1}\right]:$ [1 $\left.\mathrm{a}-d_{2}\right] 40 \mathrm{mg}$, 酢酸 $0.15 \mathrm{ml}$ を酢酸エチル $(2 \mathrm{ml})$ 中て 3 時 間還流して合成した。. 収率 $90 \%, \operatorname{mp~170~} 171^{\circ} \mathrm{C}$ ，重水素の含 量 : $d_{1} 93 \% ， d_{0} 7 \%$ (MS 4. $65\left(0.1 \mathrm{~mol} / l \mathrm{HCl} / \mathrm{C}_{2} \mathrm{H}_{5} \mathrm{OH}\right)$ 。

\section{3. 反纫速度の測定およびその計算}

反応性生成する trans-オンフィン[2]の極大吸取 $\lambda_{\max }(2.2$ 参照）を分光光度法で追跡して求めた。生成物の trans-オレフィ

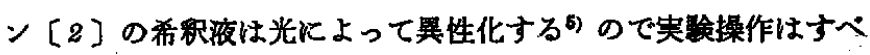
て暗所で行なった。触媒（カルボン酸，酢酸塩）の韲度は反応の 進行にとるなって生ずる酿酸の効果が無視できる範囲で行なっ た。見かけの一次速度定数 $k_{1, \mathrm{a}}$ は $\log (a-x)$ vs. $t$ のプロットの 傾き（ここで，aは[1]の初濃度，xは時間 $t$ のときの生成物 [2]の濃度を示す）から計算した。見かけの 2 次速度定数 $k_{2, \mathrm{~s}}$ は式（1）で計算した。

$$
k_{2, \mathrm{a}}=\frac{k_{1, \mathrm{a}}}{\left[\mathrm{RCO}_{2} \mathrm{H}\right]_{0}}
$$

[1 a $\left.-d_{2}\right]$ の重轻素の含量は $d_{2}$ 化合物に換算して 91\% である から $\beta$-水素同位体效果 $\left(k_{\mathrm{H}} / k_{\mathrm{D}}\right.$ の值) は次式を用いて補正した。

$$
\frac{k_{\mathrm{H}}}{k_{\mathrm{D}}}=\frac{(0.91) \cdot\left(\frac{k_{\mathrm{H}}}{k_{\mathrm{D}}}\right)_{\mathrm{app}}}{1-(0.09) \cdot\left(\frac{k_{\mathrm{H}}}{k_{\mathrm{D}}}\right)_{\mathrm{app}}}
$$

ここで, $\left(k_{\mathrm{H}} / k_{\mathrm{D}}\right)_{\mathrm{app}}$ は見かけの同位体效果で, 式 (1) から求め た $[1 \mathrm{a}]$ と $\left[1 \mathrm{a}-d_{2}\right]$ の見かけの 2 次速度定数の比である。

\section{3 結果}

\section{1 生成 物}

1-(p-ニトロフェニル)-2-(2-キノリル)エテルニアセタート[1 a を酢酸エチル溶媒中で酢酸と 3 時間反応させる $\left(80^{\circ} \mathrm{C}\right)$ と，93\% の取率で脱離生成物, trans-2-( $p$-ニトロスチリル)キノリン[2a]

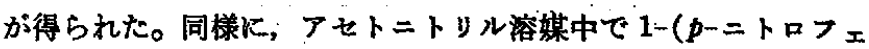
ニル)-2-(4-キノリル)エチル=アセタート[1 b 3 時間反底 $\left(80^{\circ} \mathrm{C}\right)$ させると，91\% の收率で trans $4-(p-=ト$ ロスチリル)キノリン[2 b]が得られた。これらの脱離反応は反 応速度測定条件下で定量的起こることがスペクトル的に礁嘉さ れた。ジメチルスルホキシド・水 $(22: 1 \mathrm{v} / \mathrm{v})$ 中で [1]をアセ タートアニオン（Na あるいは Li 塩として）と反応させるとカ ルボン酸触媒の揚合と同じ脱雄生成物 [2]を生ずることが澹め 
$\mathrm{N}_{\mathrm{ArCH}} \mathrm{CHAr}_{\mathrm{OAC}}$

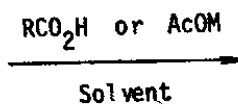

$\mathrm{NAr}_{\mathrm{H}^{\prime}} \mathrm{C}^{\mathrm{C}} \mathrm{C}_{-\mathrm{Ar}}^{-\mathrm{H}}+\mathrm{ACOH}$

[2]

[1]

[1a], [2a] : $N_{A r}=2-Q u i n o l y 1, A r=p-N i t r o p h e n y 1$

[1b], [2b]: $N_{A r}=4$-Quinoly], $A r=p-N i t r o p h e n y 1$

$$
\begin{aligned}
& \mathrm{R}: \mathrm{CH}_{3}, \mathrm{Ph}, \mathrm{ClCH}_{2}, \mathrm{Cl}_{2} \mathrm{CH}_{3} \mathrm{Cl}_{3} \mathrm{C} \\
& M: \mathrm{Na}, \mathrm{Li}
\end{aligned}
$$

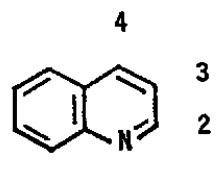

1

られた (3.4)。

1-(p-ニトロフェニル)-2-(2-キノリル)エチル-2, 2-d $d_{2}=$ ア女 一ト $\left[1 \mathrm{a}-d_{2}\right]$ は式 (4)kしたがって合成した。まず，キナル ジンと重水とを水酸化カソウム存在下， $180^{\circ} \mathrm{C}$ で 8 時間反応させ るとメチル基のプロトンが全体で 74 75\% 重水菜と交換された キナルジンー $d_{3}$ が得られた。このキナルジンー $d_{3}$ と $p$-ニトロベン ズアルデヒドとを四塩化炭妻・へキサジューテロエタノール(1:1 $\mathrm{v} / \mathrm{v})$ 中で 48 時間僄流すると $40 \%$ の収率で付加生成物，1-(pニトロフェニル)-2-(2-キノリル)エタノール-2, 2-d 斿得られ た。この付加生成物を室温でピリジン溶媒中，無水酢酸と 18 時 間反応させると $70 \%$ の収率で重水素化されたアセタート〔1 a $\left.d_{2}\right]$ が得られた。 $\left[1 \mathrm{a}-d_{2}\right]$ の $\beta$-位の重水莱の含量は $d_{2}$-化合物 飞换算して 91\% であった。 $\left[1 \mathrm{a}-d_{2}\right]$ を䣫酸エチル溶媒中, 酶酸 と 3 時間反応 $\left(80^{\circ} \mathrm{C}\right)$ させると $90 \%$ の収率で trans-2- $(p-二$ 上 ロスキリル)キノリンー $\beta-d[2 \mathrm{a}-d]$ が得られた。 $[2 \mathrm{a}-d] の \beta-$

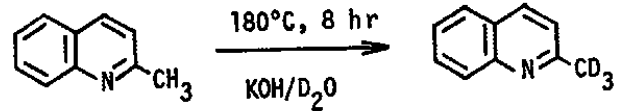

(D\%; 74-75)

Reflux, $48 \mathrm{hr}$

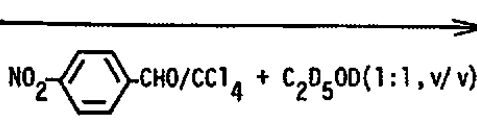<smiles></smiles>

(40\%)

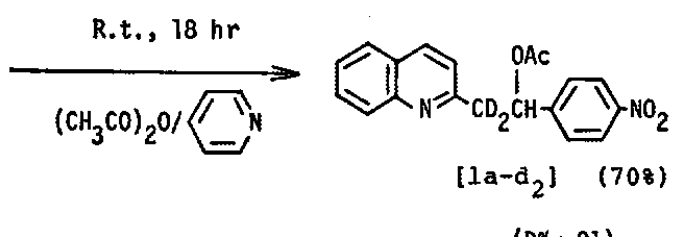

(D\%; 91)

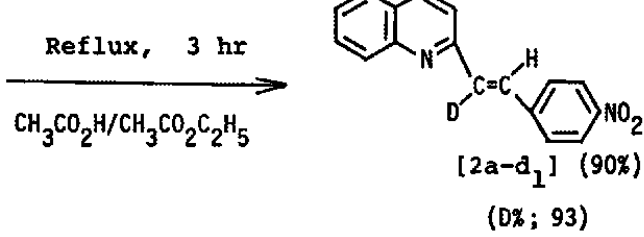

位のブロトンの重水素の含量は $93 \%$ であった。

\section{2 カルボン酸による[1]の脱離反応の速度的}

カルポン酸触媒によるアセタート[1]の脱離反応の次数につ いて唡討した。速度は生成する trans-オンフィン〔2]の極大吸 収 $\lambda_{\max }$ を追跡して求めた。カルボン酸の濃度恃反沁の進行にと るなって生ずる酶酸による速度增加が無視できる条件下で行なっ た。代表的な結果を表 1 K示した。表1からかかるように，反応 速度は基質〔1]抽よ゙カルボン酸の初濃度に1次，つまり全体

Table 1 The representative kinetic data for the carboxylic acid catalyzed elimination reactions of $1-(p$-nitrophenyl)-2-(2-and 4-quinolyl)ethyl acetates $([1 \mathrm{a}]$ and $[1 \mathrm{~b}])$ to give trans-2- and $4-(p$-nitrostyryl)quinolines $([2 \mathrm{a}]$ and $[2 \mathrm{~b}])$, respectively, in some aprotic solvents at 70.0

\begin{tabular}{|c|c|c|c|c|c|c|c|}
\hline \multirow{3}{*}{ Substrate } & \multirow{3}{*}{ Carboxylic acid } & \multirow{3}{*}{ Solvent } & \multirow{2}{*}{\multicolumn{2}{|c|}{$\begin{array}{l}\text { Initial concentration } \\
\left(\mathrm{mol} \cdot l^{-1}\right)\end{array}$}} & \multicolumn{3}{|c|}{ Rate constants } \\
\hline & & & & & $\left.k_{1, a} a\right)$ & $\left.k_{2,}^{b}\right)$ & $k_{2 \mathrm{a}}^{\mathrm{av}}$ \\
\hline & & & \multicolumn{2}{|c|}{$\widetilde{\left[\mathrm{RCO}_{2} \mathrm{H}\right]_{0}}[\overline{\text { Substrate }}]_{0}$} & $\left(s^{-1}\right)$ & $\left(l \cdot \mathrm{mol}^{-1} \cdot \mathrm{s}^{-1}\right)$ & $\left(l \cdot \mathrm{mol}^{-1} \cdot \mathrm{s}^{-1}\right)$ \\
\hline \multirow[t]{5}{*}{. } & & & $3.29 \times 10^{-2}$ & $2.88 \times 10^{-4}$ & $2.65 \times 10^{-6}$ & $6.76 \times 10^{-4}$ & \\
\hline & & & 7.76 & 2.88 & 5.47 & 7.07 & \\
\hline & (Benzoic & Dioxane & 11.8 & 2.88 & 8. 26 & 7.00 & $(6.91 \pm 0.18) \times 10^{-4}$ \\
\hline & & & 7.83 & 1. 44 & 5. 27 & 6.73 & \\
\hline & & & 7.84 & 4. 32 & 5.48 & 6.99 & \\
\hline \multirow[t]{8}{*}[1\mathrm{a}]{} & & & $0.83 \times 10^{-3}$ & 4. $12 \times 10^{-4}$ & $1.28 \times 10^{-4}$ & 1. $54 \times 10^{-1}$ & \\
\hline & Trichloroacetic & Dioxane & 1.59 & 2.63 & 2.50 & 1.57 & $(1.55 \pm 0.02) \times 10^{-1}$ \\
\hline & & & 2.29 & 1. 26 & 3.51 & 1.53 & \\
\hline & & $N, N$-dimethyl- & $0.54 \times 10^{-2}$ & 4. $25 \times 10^{-4}$ & $1.04 \times 10^{-4}$ & $1.92 \times 10^{-2}$ & \\
\hline & Dichloroacetic & $\begin{array}{l}\text { Iv, iv-aimeinyl- } \\
\text { formamide }\end{array}$ & $\begin{array}{l}1.03 \\
1.48\end{array}$ & $\begin{array}{l}2.71 \\
1.30\end{array}$ & $\begin{array}{l}1.95 \\
2.75\end{array}$ & $\begin{array}{l}1.89 \\
1.86\end{array}$ & $(1.89 \pm 0.03) \times 10^{-2}$ \\
\hline & & & $0.83 \times 10^{-3}$ & $6.09 \times 10^{-4}$ & $2.28 \times 10^{-6}$ & $2.75 \times 10^{-2}$ & \\
\hline & (Trichloroacetic & Dioxane & 1.59 & 3.88 & 4. 45 & 2.86 & $(2.81 \pm 0.06) \times 10^{-3}$ \\
\hline & & & 2.29 & 1.86 & 6.46 & 2.82 & \\
\hline \multirow{3}{*}[1\mathrm{b}]{} & & $N, N$-dimethyl- & $0.54 \times 10^{-2}$ & 5. $47 \times 10^{-4}$ & $0.80 \times 10^{-4}$ & 1. $48 \times 10^{-2}$ & \\
\hline & Dichloroacetic & formamide & 1.03 & 3.49 & 1.55 & 1.50 & $(1.51 \pm 0.02) \times 10^{-2}$ \\
\hline & & & 1.48 & 1.67 & 2.23 & 1.51 & \\
\hline
\end{tabular}
$\pm 0.1^{\circ} \mathrm{C}$

a) The apparent first order rate constant with regard to the acetate [1].

b) The apparent second order rate constant calculated by the equation (1). 
Table 2 The effects of solvent and carboxylic acid on the apparent second order rate constant $k_{2, \mathrm{a}}$ for the elimination reaction of acetic acid from quinolylethyl acetate $[1]^{a}$ )

\begin{tabular}{|c|c|c|c|c|c|c|c|}
\hline \multirow{2}{*}{ Substrate } & \multirow{2}{*}{ Solvent } & \multirow{2}{*}{$\begin{array}{l}\text { Temperature } \\
\left({ }^{\circ} \mathrm{C}\right)^{b)}\end{array}$} & \multicolumn{5}{|c|}{$10^{4} \times k_{2, \mathrm{a}}\left(l \cdot \mathrm{mol}^{-1} \cdot \mathrm{s}^{-1}\right)$} \\
\hline & & & $\mathrm{CH}_{3} \mathrm{CO}_{2} \mathrm{H}$ & $\mathrm{PhCO}_{2} \mathrm{H}$ & $\mathrm{ClCH}_{2} \mathrm{CO}_{2} \mathrm{H}$ & $\mathrm{Cl}_{2} \mathrm{CHCO}_{2} \mathrm{H}$ & $\mathrm{Cl}_{3} \mathrm{CCO}_{2} \mathrm{H}$ \\
\hline \multirow{17}{*}[1\mathrm{a}]{} & \multirow{5}{*}{$\left(\begin{array}{c}\text { Dimethyl } \\
\text { sulfoxide }\end{array}\right.$} & $50.0^{c)}$ & 0.552 & 3.08 & 9.46 & 39.5 & - \\
\hline & & 60.0 & 1.18 & 6.07 & 21.3 & 80.0 & 一 \\
\hline & & 70.0 & 2.34 & 12.5 & 43.9 & 164 & - \\
\hline & & 80.0 & 4.81 & 22.1 & 89.9 & 306 & - \\
\hline & & $50.0^{c)}$ & 0.362 & 2.10 & 9. 33 & 46.7 & 一 \\
\hline & \multirow{4}{*}{$\begin{array}{l}N, N \text {-dimethyl- } \\
\text { formamide }\end{array}$} & 60.0 & 0.846 & 4. 40 & 17.6 & 93.0 & 一 \\
\hline & & 70.0 & 1.65 & 9.25 & 37.8 & 189 & $\rightarrow$ \\
\hline & & 80.0 & 3.50 & 17.4 & 61.9 & 339 & - \\
\hline & & 50. $\left.0^{c}\right)$ & 0.475 & 1.62 & 7.98 & 75.5 & 395 \\
\hline & \multirow{3}{*}{ Dioxane } & 60.0 & 1.03 & 3.25 & 16.3 & 158 & 746 \\
\hline & & 70.0 & 2. 48 & 6.91 & 37.8 & 347 & 1550 \\
\hline & & 80.0 & 3.86 & 12.3 & 65. 1 & 625 & 2540 \\
\hline & Acetonitrile & 50.0 & 1.68 & 9. 49 & 64.2 & 706 & - \\
\hline & Ethyl acetate & 50.0 & 1. 35 & 4.11 & 24.5 & 275 & 1210 \\
\hline & Cyclohexanone & 50.0 & 1.12 & 3.80 & 24.5 & 229 & - \\
\hline & Anisole & 50.0 & 4. 92 & 16.8 & 138 & 1790 & 6840 \\
\hline & Acetophenone ${ }^{d)}$ & 50.0 & 2.38 & 9.09 & 57.7 & 510 & 一 \\
\hline \multirow{17}{*}[1\mathrm{b}]{} & \multirow{5}{*}{$\left(\begin{array}{l}\text { Dimethyl } \\
\text { sulfoxide }\end{array}\right.$} & $50.0^{(c)}$ & 0.224 & 1. 41 & 5. 26 & 38. 9 & - \\
\hline & & 60.0 & 0.505 & 2.95 & 14.5 & 84.4 & - \\
\hline & & 70.0 & 0.995 & 5.82 & 36.5 & 152 & - \\
\hline & & 80.0 & 2.07 & 11.5 & 80.8 & 313 & 一 \\
\hline & & $\left.50.0^{c}\right)$ & 0.120 & 0.877 & 5. 26 & 38.3 & - \\
\hline & \multirow{3}{*}{$\begin{array}{l}N, N \text {-dimethyl- } \\
\text { formamide }\end{array}$} & 60.0 & 0.275 & 1.79 & 9.33 & 76.0 & $\longrightarrow$ \\
\hline & & 70.0 & 0.540 & 3.71 & 19.5 & 150 & - \\
\hline & & 80.0 & 1.12 & 6.73 & 32.8 & 269 & - \\
\hline & \multirow{4}{*}{ Dioxane } & $50.0^{c)}$ & - & - & - & 6. 56 & 71.4 \\
\hline & & 60.0 & - & - & 一 & 14.1 & 133 \\
\hline & & 70.0 & 一 & - & - & 29.2 & 281 \\
\hline & & 80.0 & - & - & - & 53.6 & 441 \\
\hline & Acetonitrile & 50.0 & 0.225 & 1.33 & 13.8 & 200 & - \\
\hline & Ethyl acetate & 50.0 & 一 & $\rightarrow$ & 2. 21 & 42.8 & 331 \\
\hline & Cyclohexanone & 50.0 & 0.100 & 0.358 & 4.76 & 71.2 & $\rightarrow$ \\
\hline & Anisole & 50.0 & $\longrightarrow$ & - & 2.88 & 55.2 & 199 \\
\hline & Acetophenone ${ }^{e)}$ & - & - & 一 & - & - & 一 \\
\hline
\end{tabular}

a) Errors were within $3 \%$ b) $\pm 0.1^{\circ} \mathrm{C}$. c) Extrapolated values. d) Rate was measured at $\lambda_{\max }=383 \mathrm{~nm}$. $e$ ) Rate could not measured because of the absorption of solvent.

で 2 次である。したがって，速度は次式で示される。

$$
\frac{\mathrm{d}[2]}{\mathrm{d} t}=-k_{1, \mathrm{a}}[1]=-k_{2, \mathrm{~B}}\left[\mathrm{RCO}_{2} \mathrm{H}_{0}(a-x)\right.
$$

ここで， $k_{1, \mathrm{a}}$ 括よび $k_{2, \mathrm{a}}$ はそれぞれ見かけの 1 次および 2 次速度 定数であり， $a$ は基質 [1]の初浱度， $x$ は時間 $t$ のときの生成 物〔2]の濃度である。

\section{3〔1]の脱離反応におよぼすカルボン酸および溶媒の効果}

8 種の溶桇 (アニソール, シクロヘキサノン, 酢酸エキル, ア セトフェノン, アセトニトリル，ジオキサン， $N, N$-ジメキルホ ルムアミド, ジメチルスルホキシド)，5種のカルボン酸（酰酸， 安息香酸，モノクロロ酢酸，ジクロ口酢酸、トリクロロ酢酸）を

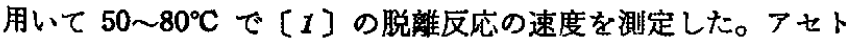
$フ_{ェ}$ フン溶某中の速度測定は溶媒の吸収のため, [1 a ] の場合は 極大吸収 $\lambda_{\mathrm{max}}=383 \mathrm{~nm}$ を追跡して求めた。[1 b $]$ の場合は溶媒 と生成物 [2 b ] の吸收が重なるため速度は追跡できなかった。結 果は表 2 に示すとおりである。

表 2 から，つぎのことがいえる。

（i）汭クロ口酸酸による脱離の見かけの 2 次速度定数の対数
値は溶媒の誘電率 $D$ とあまりよい相関珄（必ずしす直線性を意味 しない）を示すとはいえないが，【1 a の場合はDが大きくなる と速度が低下し，[1 b ] の場合は $D$ が変化しても速度は変わらな い(図 1) ${ }^{10)}$ 。しかし，[1 b の場合，Dの小さい溶媒中酸度の

10）反応速度と話電率 $D$ との関係で $\log k$ vs. $D$ のブロットは 理論的にはあまり意味をすたないが本研究の場合, [1 a $]$ と $[1 \mathrm{~b}]$ の脱離に括よ活すDの效果の違いを調べる目的で 用いた.Dのかわり飞通常用いられる1/Dあるいは $(D-1) /$ $(2 D+1)$ とのブロットをとってる図 1 と同様相関性鈊 く、いずれる [1 a 槅電事 $D$ 以外の因子として $Y$ 値, $Z$ 值， $\log k_{\text {lon }}$ などの傎 が知られているが，その定義と本研究の反応型とが異なる ため適用できない，溶媒の誘電束D恃巨視的なバラメータ 一であるが，微視的なバラメーターとして有効新電率 $\left[D_{\mathrm{B}}\right.$ : K. B. Wiberg, "Physical Organic Chemistry", John Wiley \& Sons, Inc., New York·London-Sydney(1970) p. 283] が知られているが， $D_{\mathrm{E}}$ は共鳴奻果がない分子内て の双極子と電荷との相互作用への奻果の尺度であり、本研 究の場合，律速 (透移状悲)段㳻でカルボキシラートア二オ

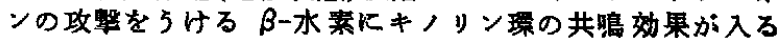
ことと，後で述べるように $\mathrm{HN}^{+}$と $\mathrm{RCO}_{2}^{-}$との相互作用 が含まれるため論議し難いと思われる、 


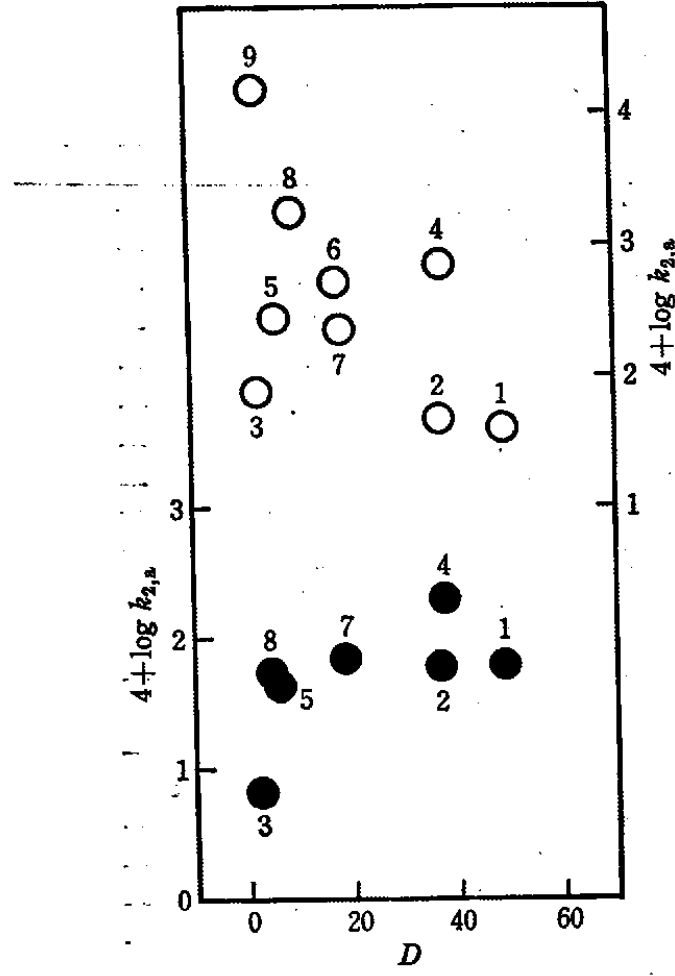

Fig. 1 Plots of $\log k_{2, \mathrm{a}}$ vs. $D$. for the dichloroacetic acid catalyzed elimination reaction of $[1]$ at $50.0^{\circ} \mathrm{C}$

Substrate-

Solvent- $[1$ a

$0:[1 \mathrm{a}], O:[1 \mathrm{~b}]$

(1) : Dimethyl sulfoxide, (2): $N, N$-Dimethylformamide, (3): Dioxane, (4): Acetonitrile, (5.) : Ethyl acetate, (6): Acetophenone, (7): Cyclohexanone, (8): Anisole, (9): Benzene

From the data in Table 2.

低いカルボソ酸による脱離速度が非常に荤く， $k_{2, \mathrm{a}}$ を求めること ができながったことを考虑すると，Dが大きくなると速度がはや くなるといえる。したがって，[1 a ]と[1 b]の脱離におよぼす

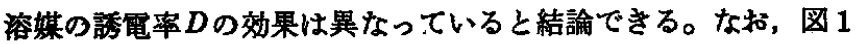
のヘンザン中での [1 a ] の脱離速度は $40^{\circ} \mathrm{C}$ での $k_{2, \mathrm{a}}=k_{5} K_{1}{ }^{8)}$ の 2 倍の値を用いた。

（ii） ジクロロ酢酸触媒による[1]の脱離反応の見かけの 2 次速度定数の対数値之溶媒の電子供与度 $\Delta \nu_{\mathrm{D}}\left(\mathrm{cm}^{-1}\right)^{1 \mathrm{l})}$ との相関 性 ( $\log k_{2, \mathrm{a}}$ vs. $\Delta \nu_{\mathrm{D}}$ のブロット) は図 2 K示すとおりである。 [ 1 a ] の脱離速度は溶媒の電子供与度 $\Delta \nu_{\mathrm{D}}$ に対して良好な負の 相関を示すか;，[1 b]の場合は $A \nu_{\mathrm{D}}$ の変化に対してあまり速度 変化がない。

(iii）【1]の脱離におよぼすカルボン酸の効果は，トリクロ

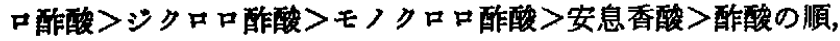
つまりカルボン酸の酸度が強くなるほど[1]の脱離速度は速く なる。

(iv) Brönsted プットを国3に示した。実験に用いた溶媒 中のカルポン酸の $p K_{a}$ 值の報告がないので水中の $p K_{a}$ 值 $^{12)}$ 用いてプロットをとったところ，誘電率の低い溶媒中の場合はか なりよい㨁線性を示したが，譑笪率の高い溶媒の場合は曲線であ った。图 3 で值線の成立する籍围でちの㑯き $\alpha$ を求めると0.39〜

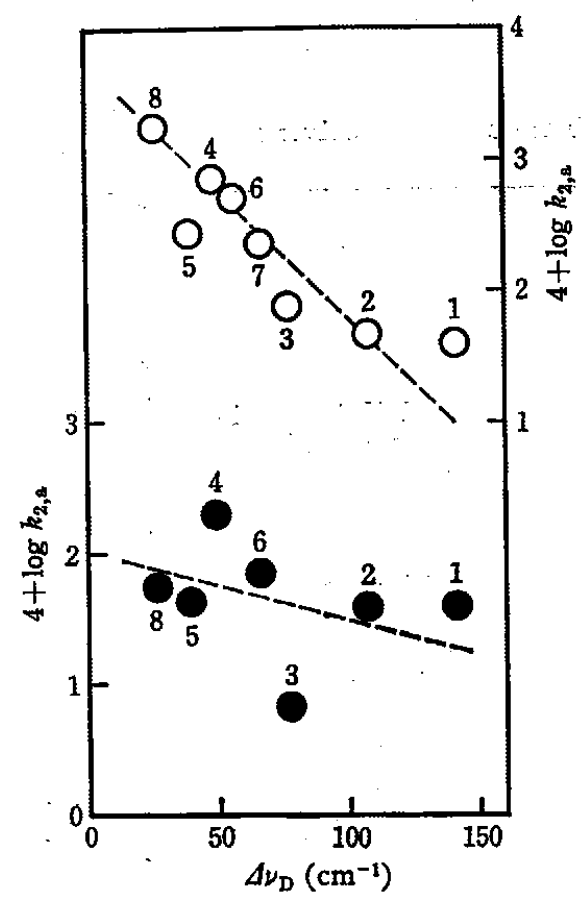

Fig. 2 plots of $\log k_{2, \mathrm{a}}$. vs. $\Delta \nu_{\mathrm{D}}\left(\mathrm{cm}^{-1}\right)$ for the dichloroacetic acid catalyzed elimination reaction of $[x]$ at $50.0^{\circ} \mathrm{C}$

Substrate-

$$
O:[1 \mathrm{a}], O:[1 \mathrm{~b}]
$$

Solvent $\longrightarrow$

(1) : Dimethyl sulfoxide, (2) : N, N-Dimethylformamide, (3): Dioxane, (4): Acetonitrile, (5) : Ethyl acetate, (6): Acetophenone, (7): Cyclohexanone, (8): Anisole

From the data in Table 2.

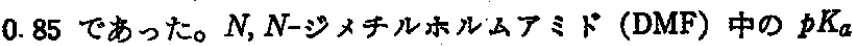
值 ${ }^{12)}$ ，相対酸度の対数值 $\log K_{\mathrm{r}}{ }^{13)}$ を用いて Brönsted のプロッ トをとると曲線であった。すなわち，DMF や䔩性の高い溶媒中 の反応の場合, Brönsted のプロットは值線を示さないと結論で きる。

3.4 酢酸ナトリウムおよび酰酸りチウムによる[1]の脱噰反 芯一アセタートアニオンの触媒作用一

若干の塩による[1]の脱離反応について検討した。塩として は酢酸ナトリウム，酢酸リチウム掠よび過塩素酸りチウムを用い た。酢酸塩は有機溶媒に対して溶解度が小さいので, 速度はジ キルスルホキシド・我 $(22: 1 \mathrm{v} / \mathrm{v})$ 溶某中 $\left(90^{\circ} \mathrm{C}\right)$ で追跡した。 また，反灾の進行にともなって生ずる䤏酸の影響を防ぐため， [塩]。 》[基質]。の条件下で速度を娜定した。結果情 3 に示すと おりである。

表 3から、つぎのことがわかる。

(i ) [1]の脱離反応はアセタートアニオン (AcOM, M= $\mathrm{Na}, \mathrm{Li})$ によって起こるが，触媒が存在しない場合，あるいは， 過塩素酸リチウムの存在下では䫄離はまったく起こらない。

11) T. Kagiya, Y. Sumida, T. Inoue, Bull. Chem. Soc. Jap., 41, 767(1968).

12）浅原照三編，妹尾 学，新井 健，“有機化学反応に扣け る溶媒効果”，産業図書(1970)p. 36.

13) S. Patai Ed., "The Chemistry of Carboxylic Acids and Esters", Interscience (1969) p. 243. 


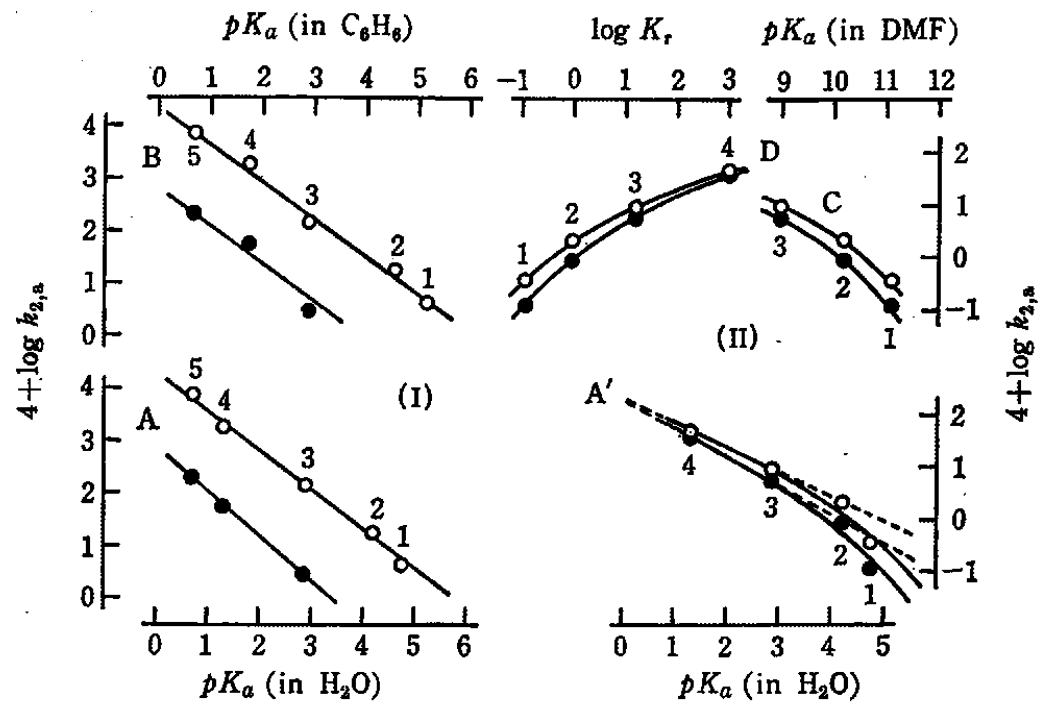

Fig. 3 Brönsted plots $\left(\log k_{2, a}\right.$ vs. $\left.p K_{a}\right)$ for the carboxylic acid catalyzed elimination of [1] in some aprotic solvents at $50.0^{\circ} \mathrm{C}$

Substrate-

$$
O:[1 \mathrm{a}], O:[1 \mathrm{~b}]
$$

Solvents-

(I) : Anisole, (II) $: N, N$-Dimethylformamide (DMF)

Carboxylic acid-

(1): Acetic acid, (2): Benzoic acid, (3): Monochloroacetic acid, Plots

(4) : Dichloroacetic acid, (5) : Trichloroacetic acid

(A).: $\log k_{2,2}$ (in anisole) vs. $p K_{a}$ (in water), (A') $: \log k_{2, \mathrm{a}}$ (in DMF) vs. $p K_{a}$

(in water), (B) $: \log _{2, a}$ (in anisole) vs. $p K_{a}$ (in benzene), (C) $: \log k_{2, a}$ (in DMF)

vs. $p K_{a}$ (in DMF), (D) $: \log k$ in DMF) vs. $\log K_{\mathrm{r}}$ (in DMF)

From the data in Table 2 and Ref. 12) and 13).

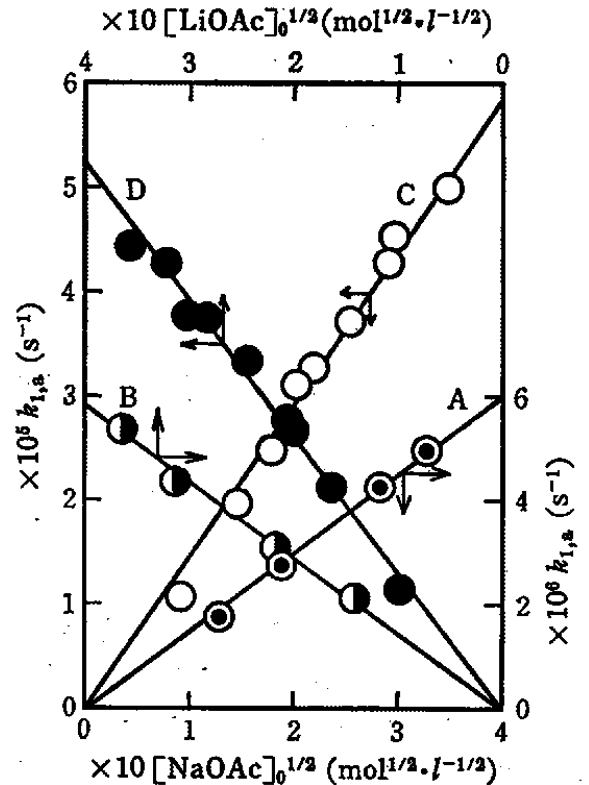

Fig. 4 Plots of $k_{1, a}$ vs. [AcOM] $]^{1 / 2}$ for the acetate anion catalyzed elimination of [1] in dimethyl sulfoxide-water $(22: 1 \mathrm{v} / \mathrm{v})$ at $90.0^{\circ} \mathrm{C}$

Substrate/AcOM
$A(\odot):[1 \mathrm{a}] / \mathrm{NaOAc}, \mathrm{B}(\mathrm{O}):[1 \mathrm{a}] / \mathrm{LiOAc}$
$\mathrm{C}(\mathrm{O}):[1 \mathrm{~b}] / \mathrm{NaOAc} ; \mathrm{D}(\mathrm{O}):[1 \mathrm{~b}] / \mathrm{LiOAc}$

From the data in Table 3.

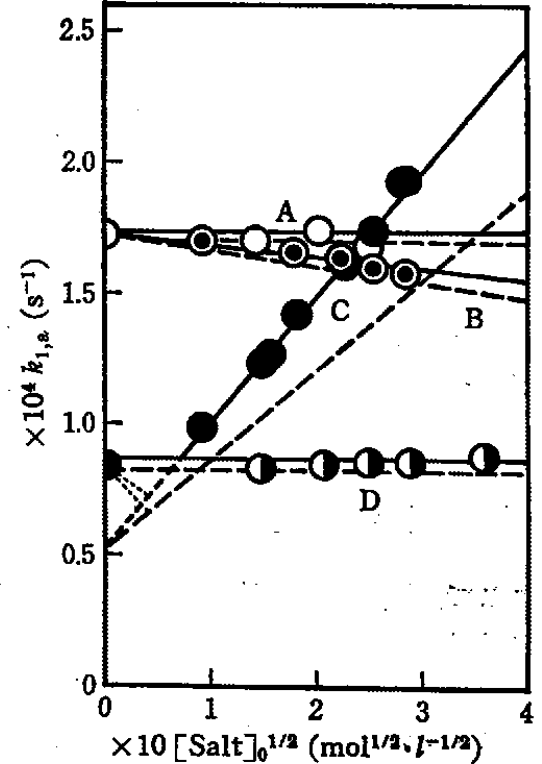

Fig. 5 Plots of $k_{1, \mathrm{~B}}$ vs. [Salt] $]_{0}^{-1 / 2}$ for the acetic acid catalyzed elimination of $[1]$ in the presence of salt in dimethyl sulfoxide-water $(22: 1 \mathrm{v} / \mathrm{v})$ at $90.0^{\circ} \mathrm{C}$

Substrate/Salt

$A(O):[1$ a $] / \mathrm{LiClO}_{4}, \mathrm{~B}(\odot):[1 \mathrm{a}] / \mathrm{NaOAc}$, $C(O):[1 \mathrm{~b}] / \mathrm{LiClO}, \mathrm{D}(\mathrm{O}):[1 \mathrm{~b}] / \mathrm{NaOAc}$ From the data in Table 4, 3.

Plots ;

- $: k_{1, \mathrm{a}}(\mathrm{Salt} / \mathrm{AcOH})$ vs. [Salt $]_{0}^{1 / 2}$

$---:\left\{k_{1, \mathrm{a}}(\right.$ Salt $\left./ \mathrm{AcOH})-k_{1, \mathrm{a}}(\mathrm{Salt})\right\}$ vs.

$[\text { Salt }]_{p}^{1 / 2}$. 
Table 3 The apparent first order rate constant $k_{1, \mathrm{e}}$ for the elimination of [1] catalyzed by some salts in dimethyl sulfoxide-water $(22: 1 \mathrm{v} / \mathrm{v})$ at 90.0 $\pm 0.1^{\circ} \mathrm{C}^{(\alpha)}$

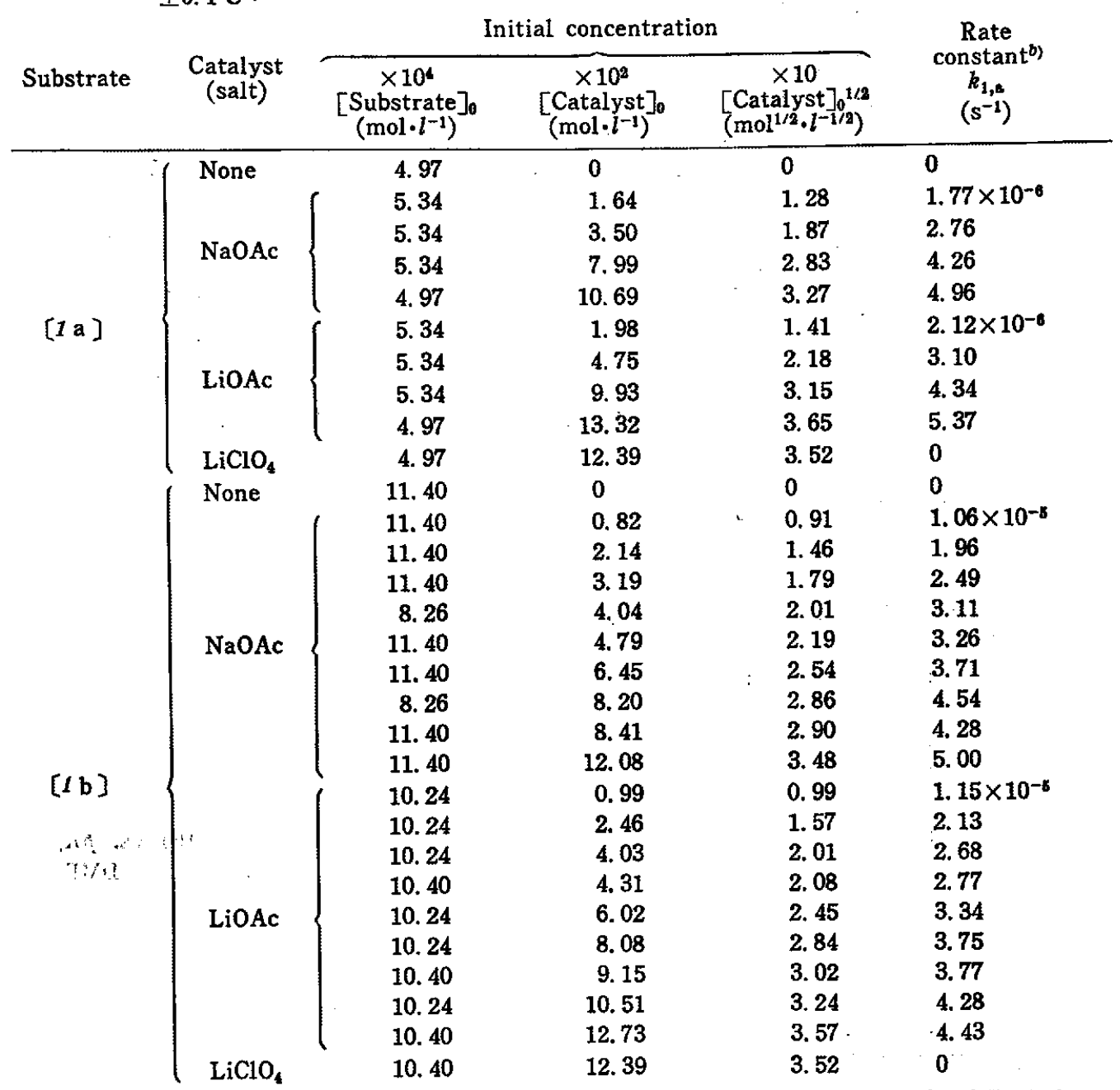

a) Rate was measured by following the absorption of the product [2] in $\mathrm{CH}_{8} \mathrm{OH}+\mathrm{H}_{2} \mathrm{O}$ $(9: 1 \mathrm{v} / \mathrm{v})$ containing $0.1 \mathrm{~mol} \cdot l^{-1}$ of hydrochloric acid.

b) The apparent first order rate constant with regard to the acetate [1]. Errors were within $5 \%$.

（ii）眖離速度は触媒の酢酸塩 $\mathrm{AcOM}(\mathrm{M}=\mathrm{Na}, \mathrm{Li})$ の初濃度 に1次ではなく，0.5 次である。すなわち，アセタートアニオン による[1]の脱離反沁の速度式は

$$
\frac{\mathrm{d}[2]}{\mathrm{d} t}=-k_{1, \mathrm{a}}[1]=-k_{3, \mathrm{a}}[\mathrm{AcOM}]_{0}^{1 / 2}(a-x)
$$

で示される。ここで， $k_{1, \mathrm{a}}$ は見かけの 1 次速度定数であり， $k_{3, \mathrm{a}}$ は見かけの 1.5 次速度定数で, $k_{3, \mathrm{a}}=k_{1, \mathrm{a}} /[\mathrm{AcOM}]_{0}^{1 / 2}$ によって計 算される。 $a$ 忙 [1] の初浱度, $x$ は時間 $t$ のときの [2]の濃 度を示す。目 4 K $k_{1 \text { a }}$ vs. [AcOM $]_{0}^{1 / 2}$ のプロットを示した。

(iii) ジメチルスルホキシド・水 $(22: 1 \mathrm{v} / \mathrm{v})$ 中, $90^{\circ} \mathrm{C}$ 飞拈 けるアセタートアニオンによる[1]の脱離速度は, 酢酸触媒の 場合よりる遅い(表 5 参照)。

3.5 ジメチルスルホキシト・水 $(22: 1 \mathrm{v} / \mathrm{v})$ 溶媒中, 酶酸に よる[1]の脱離反忘の塭類効果

酢酸による[1]の脱離反応に括よぼす塩類の効果は，眽酸塩 の有機溶媒炕対する溶解度が小さいためジメチルスルホキシド・ 水 $(22: 1 \mathrm{v} / \mathrm{v})$ 溶媒中 $\left(90^{\circ} \mathrm{C}\right)$ で行なった。結果は婊 4 k示すと キりりであった。
表 4 の結果からつぎのことがいえる。

（i）アセタートアニオンKよる[1]の脱離反応（図 4) と 同様, 反応速度は $\left.[\mathrm{AcOM}]_{0}\right]^{1 / 2}$ 々良好な線関保が成立する。四 5 K $k_{1, \mathrm{a}}$ vs. $[\mathrm{AcOM}]_{0}{ }^{1 / 2}$ のプロットを示した。 $[1 \mathrm{a}],[1 \mathrm{~b}]$ と る AcOM 単独の触媒效果があるのでその効果を差し引いたブロ ットを破線で示した。

(ii）過塩素酸りチウム $\left(\mathrm{ClO}_{4}^{-}\right)$の効果はない。

（iii） [1 a 〕場合祐干の共通陰イオン効果（反応速度の低 下）が認められ，[1 b] の場合は共通陰イオン効果のほが塩の 濃度が高いところでかなりの速度增加が認められる（図5）。

\section{6 〔1〕の脱傕反応の速度比 $r$}

$[1 \mathrm{a}]$ と $[1 \mathrm{~b}]$ の脱離の反応性の違いを速度比 $r$ Kよって検討 した。反応速度比 $r は （ 7 ）$ 式によって計算した。ここで, $k_{2, \mathrm{~s}}$

$$
r=\frac{k_{i, \mathrm{a}}([1 \mathrm{a}])}{k_{i, \mathrm{a}}([1 \mathrm{~b}])}{ }_{i=2,3}
$$

は式（5）火よって求めた見かけの 2 次速度定数であり， $k_{\mathrm{g}, \mathrm{a}}$ は 因4のプロットの傾きから計算した見かけの 1.5 次速度定数であ 
Table 4 Salt effect on the acetic acid catalyzed elimination of $[1]$ in dimethyl sulfoxide-water $(22: 1 \mathrm{v} / \mathrm{v})$ at $90.0 \pm 0.1^{\circ} \mathrm{C}^{a}$ )

\begin{tabular}{|c|c|c|c|c|c|}
\hline \multirow[b]{2}{*}{ Substrate } & \multirow[b]{2}{*}{ Salt } & \multicolumn{3}{|c|}{ Initial concentration } & \multirow{2}{*}{$\begin{array}{c}\text { Rate } \\
\text { constant } \\
\times 10^{4} k_{1, \mathrm{~s}} \\
\left(\mathrm{~s}^{-1}\right)\end{array}$} \\
\hline & & $\begin{array}{c}\times 10^{4} \\
{[\text { Substrate }]_{0}} \\
\left(\mathrm{~mol} \cdot l^{-1}\right)\end{array}$ & $\begin{array}{c}\times 10^{2} \\
{[\mathrm{Salt}]_{0}} \\
\left(\mathrm{~mol} \cdot l^{-1}\right)\end{array}$ & $\begin{array}{c}\times 10 \\
{\left[\mathrm{Salt}_{0}\right]_{0}^{1 / 2}} \\
\left(\mathrm{~mol}^{1 / 2} \cdot l^{-1 / 2}\right)\end{array}$ & \\
\hline \multirow{15}{*}[1\mathrm{a}]{} & \multirow{2}{*}{ None } & 4.58 & 0 & 0 & 1.71 \\
\hline & & \multirow{6}{*}{ 4. 58} & 0 & 0 & 1.73 \\
\hline & \multirow{5}{*}{$\mathrm{NaOAc}$} & & 0.84 & 0.92 & 1.70 \\
\hline & & & 3.19 & 1.79 & 1.66 \\
\hline & & & 4.87 & 2.21 . & 1.63 \\
\hline & & & 6.43 & 2.53 & 1.60 \\
\hline & & & 7.99 & 2.83 & 1.58 \\
\hline & \multirow{5}{*}{ LiOAc } & \multirow{5}{*}{ 4. 31} & 0.97 & 0.98 & 1.69 \\
\hline & & & 3.95 & 1. 99 & 1.66 \\
\hline & & & 6.13 & 2. 48 & 1.62 \\
\hline & & & 7.95 & 2.84 & 1.61 \\
\hline & & & 9.96 & 3. 16 & 1.60 \\
\hline & \multirow{3}{*}{$\mathrm{LiClO}_{4}$} & \multirow{3}{*}{5.03} & 2.02 & 1.42 & 1.70 \\
\hline & & & 4.08 & 2.02 & 1.74 \\
\hline & & & 6.16 & 2.48 & 1.68 \\
\hline \multirow{29}{*}[1\mathrm{b}]{} & \multirow{9}{*}{ None } & 9.89 & 0 & 0 & 0.83 \\
\hline & & 8.64 & 0 & $\mathbf{0}$ & 0.87 \\
\hline & & 9.27 & $\mathbf{0}$ & 0 & 0.83 \\
\hline & & 9.36 & 0 & 0 & 0.81 \\
\hline & & 9.45 & 0 & 0 & 0.84 \\
\hline & & 9.45 & 0.82 & 0.91 & 0.99 \\
\hline & & 9.45 & 2.17 & 1. 47 & 1. 23 \\
\hline & & 9.36 & 2.43 & 1.56 & 1.27 \\
\hline & & 9.45 & 3.23 & 1.80 & 1.42 \\
\hline & \multirow[t]{5}{*}{$\mathrm{NaOAc}$} & 9.45 & 4.92 & 2.22 & 1.64 \\
\hline & & 9.36 & 5.15 & 2.27 & 1.61 \\
\hline & & 9.45 & 6.37 & 2.52 & 1.74 \\
\hline & & 9.36 & 7.85 & 2.80 & 1.93 \\
\hline & & 9.45 & 8.05 & 2.84 & 1.93 \\
\hline & \multirow{9}{*}{$\mathrm{LiOAc}$} & 8.64 & 0.93 & 0.96 & 1.04 \\
\hline & & 8.64 & 2.46 & . 1.57 & 1.26 \\
\hline & & 9.27 & 3.11 & 1.76 & 1.33 \\
\hline & & 8.64 & 4.05 & 2.01 & 1.45 \\
\hline & & 9.27 & 6.07 & 2. 46 & 1.63 \\
\hline & & 8.64 & 6.57 & 2.56 & 1.65 \\
\hline & & 9.27 & 8.04 & 2.84 & 1.74 \\
\hline & & 8.64 & 9.72 & 3. 12 & 1.86 \\
\hline & & 8. 64 & 10.36 & 3.22 & 1.83 \\
\hline & \multirow{6}{*}{$\mathrm{LiClO}_{4}$} & 9.27 & 2.16 & 1.47 & 0.83 \\
\hline & & 9.27 & 4. 24 & 2.06 & 0.84 \\
\hline & & 9.89 & 4. 29 & 2.09 & 0.85 \\
\hline & & 9.27 & 6.20 & 2.49 & 0.86 \\
\hline & & 9.89 & 8.24 & 2.89 & 0.86 \\
\hline & & 9.89 & 12.84 & 3.58 & 0.88 \\
\hline
\end{tabular}

a) Initial concentration of acetic acid : $1.51 \times 10^{-1} \mathrm{~mol} \cdot l^{-1}$.

b) The apparent first order rate constant with regard to [1].

る。結果は荠 5 に示すと括りであった。

表 5 の結果からつぎのことがいえる。

（i） カルポン酸触媒による脱離は $r>1$, つまり[1 a の方 が $[1 \mathrm{~b}]$ よりる速度がはやい。

(ii）カルボン酸の酸度が強くなると、は小さくなる。

（iii）溶媒の極性（誘電率 D) が大さくなるとては小さくなる (図 $6: \log r$ vs. $1 / D$ )。

（iv）溶媒の電子供与度 $\Delta \nu_{\mathrm{D}}$ が大きくなると惊さくなる (図 $7: \log r$ vs. $\Delta \nu_{\mathrm{D}}$ )。

（v） アセタートアニオン触媒化よる脱離反応の場合 $r=0.10$

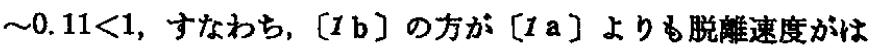
やい。

3.7 酢酸エチル中, カルボン酸による $[1 \mathrm{a}]$ の脱䧸反応の $\beta$ 水素同位体効果 $\left(\boldsymbol{k}_{\mathrm{H}} / \boldsymbol{k}_{\mathrm{D}}\right)$

〔1]のカルボン酸による脱離反応の律速段階，遷移状態のよ らすを知るため 1-(p-ニトロフェニル)-2-(2-キノリル)エキルー 2,2- $d_{2}=$ アセタート [1 $\left.\mathrm{a}-d_{2}\right]$ を合成 (3.1) してその脱離速度を测 定した。ß-水素同位体効果の結果は表 6 のとおりであった。ここ で, $\left(k_{\mathrm{H}} / k_{\mathrm{D}}\right)_{\mathrm{Bpp}}$ は $[1 \mathrm{a}]$ および $\left[1 \mathrm{a}-d_{2}\right]$ の見かけの 2 次速度定 数の此である。 $\left[1 \mathrm{a}-d_{2}\right]$ は $d_{2}$-化合物に換算して重水素の含昷が 
Table 5 The ratio $r$ of the apparent rate constant for the carboxylic acid or acetate anion catalyzed elimination reaction of $[1]^{a)}$

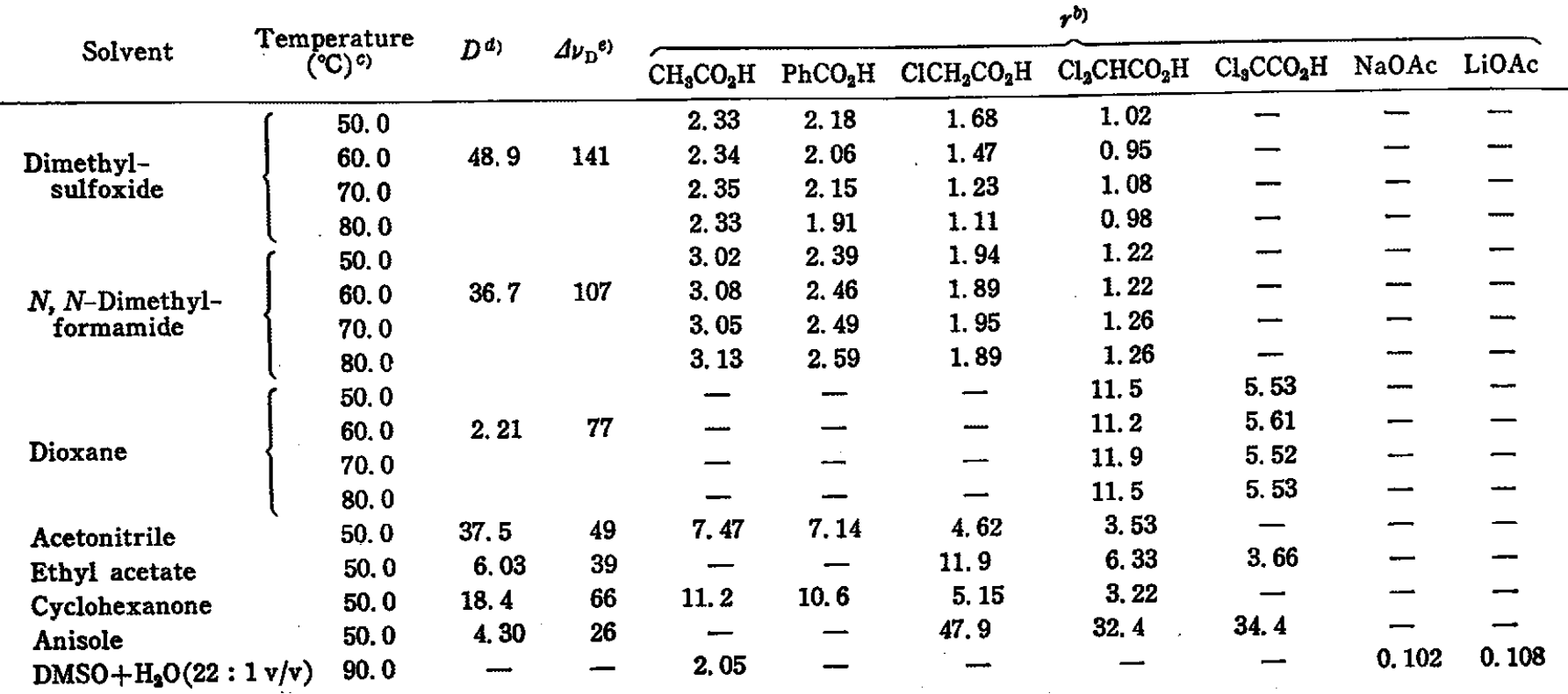

a) Errors were $5 \sim 10 \%$.

b) $r=k_{i, \mathrm{a}}([1 \mathrm{a}]) / k_{i, \mathrm{a}}([1 \mathrm{~b}]) ; i=2,3$. Calculated from the data in Table 2 and 4 .

c) $\pm 0.1^{\circ} \mathrm{C}$.

d) Dielectric constant of solvent, Ref. 14).

e) The electron donability of solvent, Ref. 11).

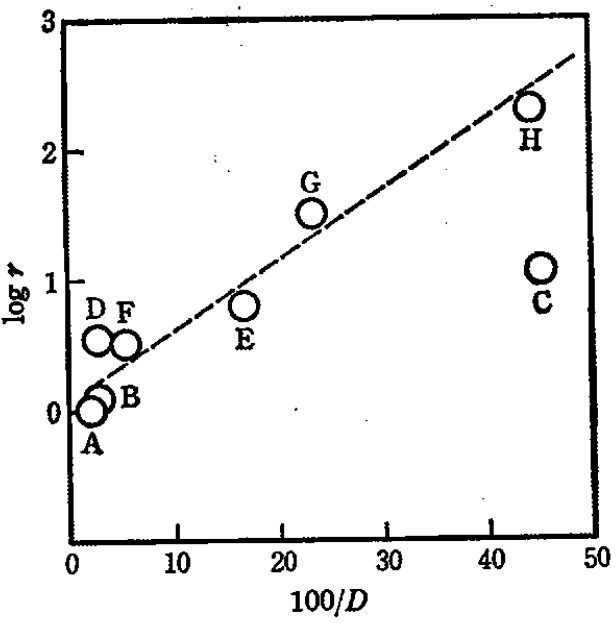

Fig. 6 A plot of $\log r$ vs. $1 / D$ for the dichloroacetic acid catalyzed elimination of $[1]$ at $50.0^{\circ} \mathrm{C}$

Solvent-

(A) : Dimethyl sulfoxide, (B) : N,N-Dimethyl-

formamide, (C) : Dioxane, (D) : Acetonitrile,

(E) : Ethyl acetate, (F) : Cyclohexanone, (G):

Anisole, (H) : Toluene

From the data in Table 5 and Ref. 15).

91\%であるから式 (2) を用いて $k_{\mathrm{H}} / k_{\mathrm{D}}$ を補正した。これらの補 正値は表 6 の 3 列目に併記した。

表 6 の結果からつぎのことがいえる。

14）文献 12）の p.68; 文献 6) の “Organic Solvents”, Chapter III, p. 66.

15）トルエン溶媒中, $\left[\mathrm{Cl}_{2} \mathrm{CHCO}_{2} \mathrm{H}\right]_{0}=6.85 \times 10^{-4} \mathrm{~mol} \cdot l^{-1}$ のと き, $k_{1, \mathrm{a}}$ 江 [1 a ] の堎合 $3.5 \times 10^{-4} \mathrm{~s}^{-1}\left(40^{\circ} \mathrm{C}\right),[1 \mathrm{~b}] の$ 場合, $6.7 \times 10^{-6} \mathrm{~s}^{-1}\left(60^{\circ} \mathrm{C}\right)$ であるから，温度协果を考虑 に入れると $r \fallingdotseq 200$ となる。 未発表データ。

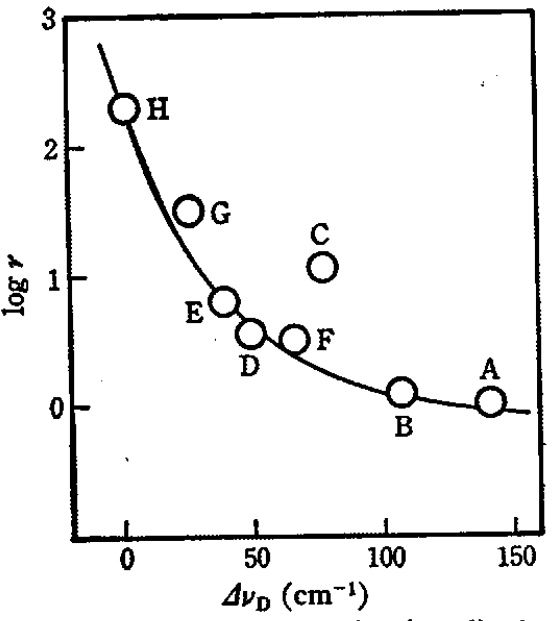

Fig. 7 A plot of $\log r$ vs. $\Delta \nu_{\mathrm{D}}\left(\mathrm{cm}^{-1}\right)$ for the dichloroacetic acid catalyzed elimination of $[1]$ at $50.0^{\circ} \mathrm{C}$

Solvent -

(A) : Dimethyl sulfoxide, (B) : $N, N$-Dimethylformamide, (C) : Dioxane, (D) : Acetonitrile,

(E) : Ethyl acetate, (F) : Cyclohexanone, (G):

Anisole, (H) : Toluene

From the data in Table 5 and Ref. 15).

(i ) $\beta$-水素同位体効果 $\left(k_{\mathrm{H}} / k_{\mathrm{D}}\right.$ の值) は1よりる大きいす なわら， $\beta$-水素の脱離が律速である。

（ii）触煤が酶酸からトリクロロ醀酸へとかわるにつれて, $k_{\mathrm{H}} / k_{\mathrm{D}}$ の值は最初は大きくなり，極大を経てついには減少する。

\section{4 考察}

\section{1 カルボン酸による[1]の脱離反忘の機構}

1-(p-ニトロフェニル)-2-(2-および 4-キノリル)エチルニ゙セ 
Table 6 Kinetic isotope effect on the carboxylic acid catalyzed elimination reaction of $[1 \mathrm{a}]$ in ethyl acetate at $\left.50.0 \pm 0.1^{\circ} \mathrm{C}^{a}\right)$

\begin{tabular}{|c|c|c|c|c|}
\hline Carboxylic acid & Base $^{b)}$ & $\left.\left(k_{\mathrm{H}} / k_{\mathrm{D}}\right)_{\mathrm{BpD}} \mathrm{c}\right)$ & $k_{\mathrm{H}} / k_{\mathrm{D}}{ }^{d)}$ & Transition state \\
\hline Acetic & $\mathrm{CH}_{3} \mathrm{CO}_{2}^{-}$ & 4.04 & 5.79 & E $1 \mathrm{cB}-$ like \\
\hline Benzoic & $\mathrm{PhCO}_{2}^{-}$ & 4. 29 & 6.35 & \\
\hline Monochloroacettic & $\mathrm{ClCH}_{2} \mathrm{CO}_{2}^{-}$ & 4.74 & 7.52 & E 2 central \\
\hline Dichloroacetic $\therefore$, & $\mathrm{Cl}_{2} \mathrm{CHCO}_{2}^{-}$ & 4.10 & 5. 91 & \\
\hline Trichloroacetic & $\mathrm{Cl}_{8} \mathrm{CCO}_{2}^{-}$ & 2.90 & 3. 57 & E 1-like \\
\hline $\begin{array}{l}\text { a) Errors were } \\
\text { b) The attacki } \\
\text { c) The appare } \\
\left(k_{\mathrm{H}} / k_{\mathrm{D}}\right)_{\mathrm{apD}} \\
\text { d) Calculated }\end{array}$ & $\begin{array}{l}\text { rithin } 5 \% \\
\text { base on } \beta \\
\text { kinetic isotc } \\
([1 \mathrm{a}]) / k_{2,8} \\
\text { equation }(2\end{array}$ & $\begin{array}{l}\text { drogen. } \\
\left.\left(1 \mathrm{a}-d_{2}\right]\right)\end{array}$ & y the & ion ; \\
\hline
\end{tabular}

る。〔1 a]の $\beta$-水塞同位体效果 ( $k_{\mathrm{H}} / k_{\mathrm{D}}$ の值) が 1 より大きい (3.7) から，E1機構 [4]が否定されると同時に， $\beta$-水素の脱 離が律速であることがわかる。

$$
\begin{array}{r}
\mathrm{ArCH}_{2} \mathrm{CHA}_{\boldsymbol{t}} \\
-\mathrm{OAC}
\end{array}
$$

における〔1〕の脱離速度におよばすカルボン酸の効果は、トリ

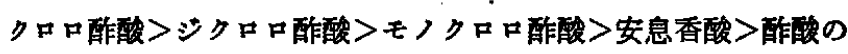
順であった (3.3)。、これらの結果はカルボン酸による[1]，の脱 倠反応がカルポン酸のキノりン空素へのプロ、トソ化を経て起こる

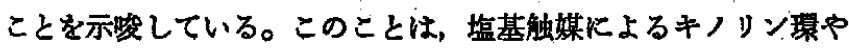
ピリジン環の 2-およよ゙ 4-位の側鎖メチル基とカルボニル化合物 との縮合反応1)，あるいは H-D (T) 交換反応 四級塩>N-オキシド>遊離塩基の順，すなわち，空素原子上の正 の電荷が大きいほど例鎖メチル基の活性（酸性）が高くなること によって支持される。したがって，カルボン酸仗よる[1]の脱 離の反応種は［3]であると結論できる。

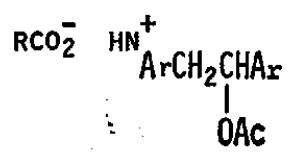

カルボン酸が[1]のキノリン空素にプロトン化して生ずる反 応種〔3]は，酸と第三級アミンから生成する四級塩である。 Kosower は,ピリジンとヨウ化アルキルから生ずる四級塩は溶

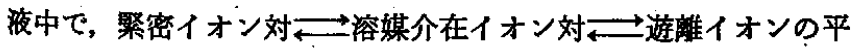
衡混合物として存在することを報告している16)。〔3〕b同様に 考えられる。ジメチルスルホキシド・我 $(22: 1 \mathrm{v} / \mathrm{v})$ 溶媒中， 90 ${ }^{\circ} \mathrm{C}$ における酢酸による[1]の脱離反応で共通陰イオン効果があ り，翼種アニオンの好果がないことから，[3]は解離していな いと考古られる。また，酢酸塩 AcOM はジメチルスルホキシド

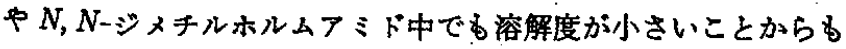
このことは支持される。カルポン酸による〔1]の脱離反応にお よぼす溶媒効果が基質によって異なる（図 1，2）ことはなんらか の形で溶媒が反応に関与している，つまり溶媒介在イオン対がこ の脱離反応に関伱していることを示唆している。 $[1 \mathrm{a}]$ と $[1 \mathrm{~b}]$ の脱離の溶媒効果は異なっているが，カルボン酸の效果が同じ (3.3) であることから両基質は同一の機構を経ていると考えられ

16) E. M. Kosower, J. Amer. Chem. Soc., 78, 3493(1956).

\section{[4]}

以上の零実に基ついて，カルボン酸による[1]の脱離反応の 機構としてつぎのすのを烤た。ここで， $K_{i}(i=1,2)$ は平衡定

$$
\mathrm{RCO}_{2} \mathrm{H}+[1] \frac{\mathrm{R}_{1}}{\text { East }} \mathrm{RCO}_{2}^{-} \cdot \mathrm{HN}_{\mathrm{ArCH}_{2}{ }_{\mathrm{OAC}}^{+}}^{\mathrm{CHAx}}
$$

[5]

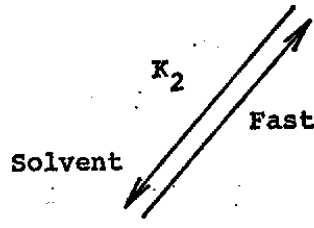

$$
\begin{aligned}
& \mathrm{RCO}_{2}^{-} / / \mathrm{HN}^{+} \\
& \left.\right|_{O A C} \underset{\text { slow }}{\mathrm{ArCH}_{2} \mathrm{CHAx}_{6}^{+}} \stackrel{\mathrm{k}_{6}}{\longrightarrow}[2]+\mathrm{CH}_{3} \mathrm{CO}_{2} \mathrm{H}+\mathrm{RCO}_{2} \mathrm{H}
\end{aligned}
$$

[6]

数, $k_{j}(j=5,6)$ は 1 次速度定数である。

まず,カルボン酸が[1]のキノリン公素にブロトン化して緊 密イオン対 [5]を生し，この[5]の一部が溶媒分子と反応（相 互作用）して溶媒介在イオン対 [6]艺生ずる。イオン対 [5]お よび [6] の対陰イオン，カルボキシラートアニオンがそれぞれ の $\beta$-水秦を E 2 型で攻撃して trans-オレフィン〔2]を生ずる。 ここで, 後の段階が律速である。

\section{2 カルボン酸による〔1]の眖離反応の速度式}

式（8）の機構について速度式をたてるとつぎのようになる。 $k_{\mathrm{H}} / k_{\mathrm{D}}>1$ ，つまり，カルボキシラートアニオンの $\beta$-水素攻帮が 律速であるから（9）式がなり立つ。

$$
\frac{\mathrm{d}[2]}{\mathrm{d} t}=-k_{\mathrm{b}}[5]-k_{\mathrm{B}}[6]
$$

ここで, 

$[5]=K_{1}\left[\mathrm{RCO}_{2} \mathrm{H}\right][1]$
$[6]=K_{2}[5][$ Solvent $]=K_{2}{ }^{\prime}[5]$
$[1]_{0}=[1]+[2]+[5]+[6]=a$
$[2]=x$

であるから，式（10）と式（9）から

$$
\frac{\mathrm{d}[2]}{\mathrm{d} t}=-\frac{\left(k_{8}+k_{8} K_{2}^{\prime}\right) K_{1}\left[\mathrm{RCO}_{2} \mathrm{H}\right](a-x)}{1+K_{1}\left[\mathrm{RCO}_{2} \mathrm{H}\right]+K_{1} K_{2}^{\prime}\left[\mathrm{RCO}_{2} \mathrm{H}\right]}
$$

が得られる。ここで，[1]》[5]+[6]，すなわち，1》K $\left[\mathrm{RCO}_{2} \mathrm{H}\right]+K_{1} K_{2}^{\prime}\left[\mathrm{RCO}_{2} \mathrm{H}\right]$ とすると, 式 (10) 㤌

$$
\frac{\mathrm{d}[2]}{\mathrm{d} t}=-\left(k_{5}+k_{6} K_{2}{ }^{\prime}\right) K_{1}\left[\mathrm{RCO}_{2} \mathrm{H}\right]_{0}(a-x)
$$

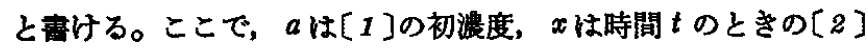
の濃度を示す。

式（5）と式 (11') 加

$$
k_{2, \mathrm{a}}=\left(k_{6}+k_{6} K_{2}^{\prime}\right) K_{1}=\text { Constant }
$$

そ㧍ける，つまり見かけの 2 次速度定数は一定である。このこと は表 1 の結果と一致する。

\section{3 イオン对 ([5]，[6]) のモテル}

カルボン酸による[1]の脱離反応の溶媒好果, 反応速度比 $r$, Brönsted のプロットの非直線性，アセタートアニオンの酢酸に よる $[1 \mathrm{~b}]$ の脱離の速度促進効果を説明するため, 祭密イオン対 [5]和よび溶媒介在イオン対 [6]の立体モデルを仮定した。 Kosower は 1-アルキルピリジニウムのヨウ素塩の立体構造とし てョウ素アニオンがピリシン瓌平面に対して垂直な直線上飞位置 するモデルを報告している17。〔5〕はカルボン酸がキノリン窒 秦にプロトン化して生した四級塩であり，〔6]は〔5]に溶媒分 子が関与（相互作用）して生ずる化合物であるから，これらは1アルキルピリジニウム塩と同じ形，すなわち，対侩イオンのカル ボキシラートアニオンがキノリン環平面に対しての垂線上に位置 していると教克てよい。

カルボン酸が $[1 \mathrm{a}] ，[1 \mathrm{~b}]$ のキノリン䇪素にプロトン化して 生ずる緊密イオン対をそれぞれ[5a]，[5b]で示した。すなわ ち,

1）正電荷はキノリニウム環の鏜素原子上飞局在する.

2）カルボキシラートフニオンは環平面の䇪素原子の垂線上に 位置する。

3）溶媒分子（坬立電子対）の[5]への相互作用（溶媒介在 イォン対 (6] の生成) 性環平面の上部( $\pi$ 平面化沼って), $\stackrel{+}{\mathrm{N}}-\mathrm{H}$ 結合の水素原子から窒素原子の方向（矢印 Aの方向） に起とる.

4）イオン対の電荷分離は $\mathrm{C}_{7}-\mathrm{N}$ 直線方向飞起こるとする.

5）反応性はカルボキシラートフニオンと $\beta$-水素間の距離で 決定される。

ここで, $[5 \mathrm{a}]$ と $[5 \mathrm{~b}]$ の立体モデルで, 結合距離 $d$, 結合角 $L, \mathrm{C}_{7}-\mathrm{N}$ 間の距離をつぎのようと的くと要),

17) E.M. Kosower, J. Amer. Chem. Soc., 80, 3267 (1958); 文献 12) の p. 66 .

18）イオン対の立体モデルは定性的な説明の目的のすのであり， 結合距離や結合角任一般の化合物の値を用いた。また，計 算して得られた $2.9 \AA ４ .4 \AA$ の数值そのるのはあまり重 要ではなく，その大小関係を考察の対象としている。

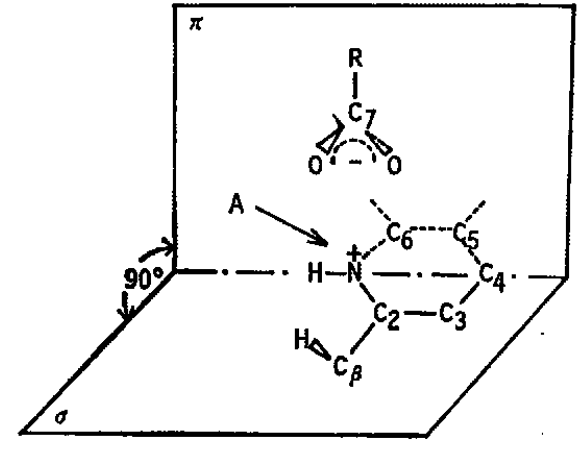

[5a]

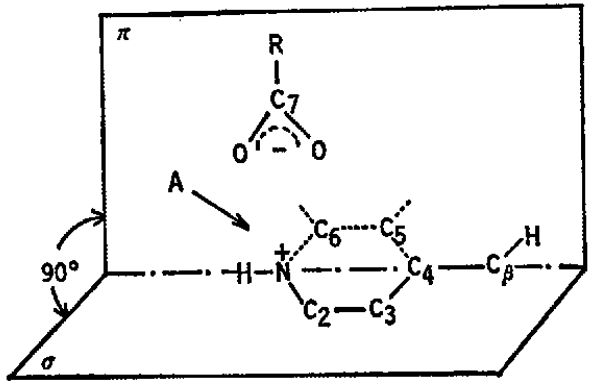

$[5 \mathrm{~b}]$

$d_{\mathrm{C}_{2}-\mathrm{N}}=d_{\mathrm{C}_{2}-\mathrm{C}_{3}}=d_{\mathrm{C}_{3-} \mathrm{C}_{4}}=1.4 \dot{\mathrm{A}}, d_{\mathrm{C}_{2}-\mathrm{C}_{\beta}}=d_{\mathrm{C}_{4}-\mathrm{C}_{\beta}}=1.5 \dot{\mathrm{A}}$,

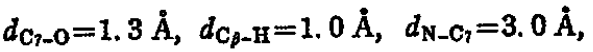
$L_{\mathrm{C}_{6} \mathrm{NC}_{3}}=L_{\mathrm{NC}_{2} \mathrm{C}_{3}}=L_{\mathrm{C}_{2} \mathrm{C}_{3} \mathrm{C}_{4}}=L_{\mathrm{C}_{3} \mathrm{C}_{4} \mathrm{C}_{5}}=L_{\mathrm{OC}_{7} 0}=L_{\mathrm{C}_{2} \mathrm{C}_{\mathrm{P}} \mathrm{H}}$ $=L_{\mathrm{C}_{4} \mathrm{C}_{\beta} \mathrm{H}}=120^{\circ}$

カルボニル酸素と $\beta$-水素間の距離は $[5 \mathrm{a}]$ の場合, $2.9 \AA$, [5 b ] の場合は $4.4 \AA$ となる。すなわち，[5a]の方が $[5 \mathrm{~b}]$ よりも カルボキシラートアニオンが $\beta$-水素に近いところに位首する。 したがって，[5a]の方が [5b]より立体的に反応が起こりやす い。たとえばトルエン中で性反応は緊密イオン対 [5] から起こ り、ジクロ口酰酸の初濃度が $6.85 \times 10^{-4} \mathrm{~mol} / \mathrm{l}$ のをき，見かけの

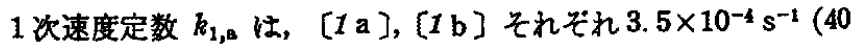
$\left.{ }^{\circ} \mathrm{C}\right), 6.7 \times 10^{-6} \mathrm{~s}^{-1}\left(60^{\circ} \mathrm{C}\right)$ である ${ }^{15)}$ このことは，立体モデル [5 a ], [5 b ] は反応性を論ずるのに满足することを示す。

溶媒はキノリニウム平面の上方から $\mathrm{H}-\mathrm{N}$ 結合の水素原子から 公素原子の方向に正の電荷 $\mathrm{N}^{+}$の部分を攻撃して溶媒介在イオン 対 [6]を生成する。したがって，[6]の場合は，カルボキシラ ートアニオンは窒素原子垂線上からずれ，C、近くなる。したが って，[6a] の場合はカルボキシラートアニオンと $\beta$-水素間の

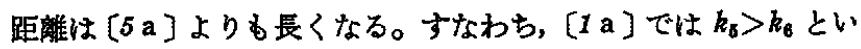
之る。 $[6 \mathrm{~b}]$ の場合怕逆佂，カルボキシラートアニオンは $[5 \mathrm{~b}]$

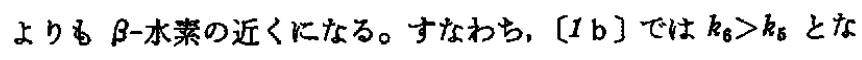
る。

\section{4 カルボン酸の触媒作用}

〔1]の脱離反応でもっとも特徽的なこと注カルボン酸の触媒 作用であるカルボン酸は[1]のキノリン窒素にプロトン化し てイオン対 [5]，[6]を形成し，カルボキシラートアニオンを 生ずるとともに[1]の $\beta$-水素を活性化する。この段階が脱離反 态を容易にしている。

式（5）で示したよらに，カルボン酸による[1]の脱離速度は カルボン酸の初濃度に 1 次，すなわち，反応全体として（速度論 的には）一般酸触媒で起こる。しかし， $N, N$-ジメチルホルムア 


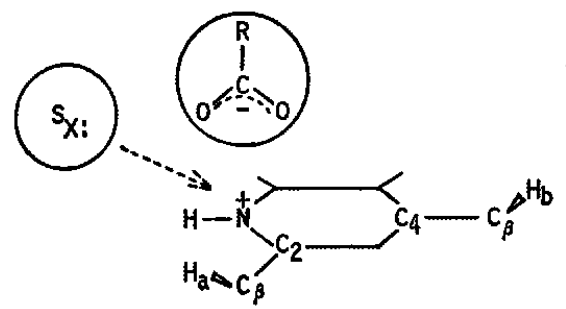

[5]

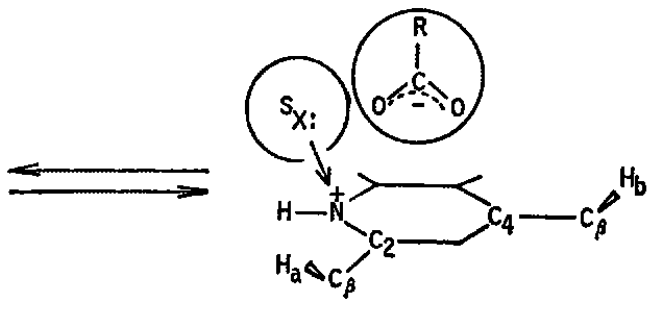

[6]

ミド中での脱離の Brönsted プロットは曲線を示す。これは式 （12）で説明できる。既報でベンゼン中 [1 a $]$ のカルボン酸触媒 脱離反応の速度論的研究からブロトン化の段階は特殊酸触媒で起 こることを報告しだ)。本研究の場合も同様に考えてよい。とこ ろが，式 (12) の第 2 項 $k_{5}+K_{2}{ }^{\prime} k_{8}$ で $k_{5}, k_{6}$ はカルボキシフー トアニオンの $p K_{a}$ 值関係する值であるか，イオン奶という特 殊条件下にあるため， $k_{6} ， k_{6}$ はカルボキシラートアニオンと $\beta$-水

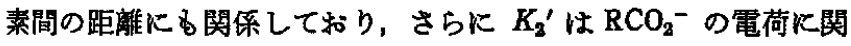
係する值であるから $\log \left(k_{5}+K_{2}{ }^{\prime} k_{6}\right)$ は必ずしす $p K_{a}$ K比例す るとはが゙らない。したがって，Brönsted プロットが曲線にな ったすのと考元られる。 $\beta$-水素同位体効果 $\left(k_{\mathrm{H}} / k_{\mathrm{D}}\right.$ の値)が 1 上 り大きいことはカルボキシラートアニオンの $\beta$-水素攻撃が一般 塩基触媒で起こることを示す。以上の事実から，カルポン酸住よ る[1]の脱離反纫忙特殊酸・一般塩基 (速度論的炕は一般酸) 触媒で起こっていると結論できる。

\section{5 溶媒奻果}

$[1 \mathrm{a}]$ と $[1 \mathrm{~b}]$ の脱離の溶媒效果が異なっている（図 1，2)こ とは溶媒が反応に関与している，すなわち，溶媒介在イオン対 〔6]が中間に存在することを示唆している。[1]の脱離の溶媒 効果は複㒕な因子が入り込んでいるため詳しく議論することはで きないが、イオン対の立体モデルを用いて定性的ではあるが説明 できる。

溶媒の電子供与度 $\Delta \nu_{\mathrm{D}}$ はカチオンを溶媒和する能力の尺度で あるから、カルボン酸の反応種は[7]，才なわち，カルボン酸

$$
\mathrm{RCO}_{2} \mathrm{H} \cdots \cdots: \text { :XS }
$$

[7]

：XS；溶媒分子

$\mathrm{X}$; 酸素, 窒素原子

のプロトンと溶媒の孤立電子対とが相互作用（水素結合）した形 である。電子供与度が大きくなるとそれだけ水素結合が強くなり， カルボン酸の酸度が低下する。したがって，K，花小さくなる。 る5一つの作用は [5]のカチオン $\mathrm{HN}^{+}$に対する相互作用であ る。電子供与度が大きい溶媒はそれだけカチオン $\mathrm{HN}^{+}$に対して
配位しやすくなる，すなわち， $K_{2}$ が大きくなる。[1 a $]$ の場合 は, $k_{6}>k_{8}$, 寸なわち，[5]加の脱離が起こりやすく,ブロト ン化の段階か特殊酸触媒で起こるから $K_{1}$ が大きく反応関与す るため図 2 のよらな负の相関性を示したるのと考えられる。[1 b ] の場合は $k_{8}>k_{5}$ であるから $[6]$ からの脱離 $\left(k_{6} K_{2}{ }^{\prime}\right)$ の重みが 大きくなる。 $K_{1}$ と $K_{2}^{\prime}$ との相殺作用のため四 2 と示すような結 果になったるのと考えられる。

溶媒の誘電率はカルボキシラートアニオン $\mathrm{RCO}_{2}$ ○とカチオン $\mathrm{HN}^{+}$との相互作用 (Coulomb 引力) に関係する。誘電率が大き くなると $\mathrm{RCO}_{2}^{-}$と $\mathrm{HN}^{+}$間の Coulomb 引力が小さくなる, つま り， $\mathrm{RCO}_{2}^{-}$と $\mathrm{HN}^{+}$間の距離が長くなり， $K_{1}, k_{5}$ が小さくなり, また溶媒がカチオン $\mathrm{HN}^{+}$を配位しやすくなるから $K_{2}$ 恃大きく なる。したがって， $k_{5}+k_{8} K_{2}{ }^{\prime}$ の各項への寄与が $[1 \mathrm{a}]$ と $[1 \mathrm{~b}]$ と異なるため $D$ に対して異なったよらすを示すと考えられる（因 1) ${ }^{10 \%}$ 。

表 2 で, $[1 \mathrm{a}]$ の場合反応珄はアニソール $\left(D=4.30, \Delta \nu_{\mathrm{D}}=\right.$ 26)>ジオキサン $\left(D=2.21, \Delta \nu_{D}=77\right), \quad$ アトニトリル $(D=$ $\left.37.5, \Delta \nu_{D}=49\right)>N, N$-ジメチルホルムアミド $\left(D=36.7, \Delta \nu_{D}=\right.$ 107）である。これらの例は反応が速い溶媒は $\Delta \nu_{\mathrm{D}}$ が小さいっつ まり $K_{1}$ が大きく作用していることを示す。 $[1 \mathrm{~b}]$ の場合, ア二 ソール $N, N$-ジxチルホルムアミドである。 $\Delta \nu_{\mathrm{D}}$ が $K_{1}$ に関与 するかぎりではアニソール>N, $N$-ジメキルホルムアミドとなる はずである。この例は， $\Delta \nu_{\mathrm{D}}$ が $K_{2}$ 亿す作用することを示晙する 之同時に, $[1 \mathrm{~b}]$ の脱離は [6]から起こる割合（重み）が大き いことを示している。

上記のように $[1]$ の脱離, つまり， $k_{2, \mathrm{a}}$ には溶媒の燯電率 $D$, 電子供与度 $\Delta \nu_{\mathrm{D}}$, さらKカルボン酸の酸度, カルボキシラートア ニオンと $\beta$-水素間の距離などが関係して $[1 \mathrm{a}]$ と $[1 \mathrm{~b}]$ の溶媒 効果が果なったよりすを示したと考兄てよい。

\section{6 アセタートアニオンによる[1]の眖離反応}

表3に示したよらに〔1]の脱離はアセタートアニオン $\mathrm{AcO}^{-}$ (AcOM，M=Na， Li として) Kよって起こるが, 触某が存在しな い場合あるい性過堨素酸アニオン $\mathrm{ClO}^{\circ}$ てよよっては起こらない。 これはアニオンの塩基性が $\mathrm{AcO}^{-}>\mathrm{ClO}_{4}^{-}$であることによる。こ の反応はジメチルスルホキシド・办 $(22: 1 \mathrm{v} / \mathrm{v})$ 中, $90^{\circ} \mathrm{C}$ で行

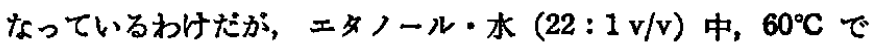
はアセタートアニオンの触媒作用は諗妨れていない19)。これは 反応温度が異なることと、アニオンの篮基性による，すなわち， ジメチルスルホキシドのよらなカチオンを溶媒和する溶媒中では アニオン $\left(\mathrm{CH}_{8} \mathrm{CO}_{2}\right.$ - $)$ は裸の状態であり反応性が高い。したがっ て, アセタートアニオンの [1]のß-水素攻撃が可能となる。

酢酸塩 $\operatorname{AcOM}(\mathrm{M}=\mathrm{Na}, \mathrm{Li})$ は溶媒中では，つぎの平衡が成立

$$
\mathrm{AcOM} \stackrel{K_{3}}{\rightleftarrows} \mathrm{AcO}^{-}+\underset{\mathrm{M}=\mathrm{Na}, \mathrm{Li}}{\mathrm{M}^{+}}
$$

する。ここで， $K_{8}$ 恃平衡定数を示す。式 (14) で生ずるアせタ ートアニオンが $\beta$-水素を攻撃するから，反応機構恃次式で示さ れる。すなるち、

$$
[1]+\mathrm{AcO}^{-} \stackrel{k_{7}}{\longrightarrow}[2]+\mathrm{AcO}^{-}+\mathrm{AcOH}
$$

19) H. Hirata, M. Hayakawa, K. Fukuzumi, Bull. Chem. Soc. Jap., 投稿中. 
ここで， $k_{7}$ は 2 次速度定数である。

式（14)，(15）から速度式をたてると

$$
\frac{\mathrm{d}[2]}{\mathrm{d} t}=-k_{7}[1]\left[\mathrm{AcO}^{-}\right]=-k_{7} K_{\mathrm{s}}^{1 / 2}[\mathrm{AcOM}]^{1 / 2}(a-x)
$$

が得られる。ここで、 $a$ は〔1]の初濃度, x性間 $t$ のとさの [2]の濯度を表わす。AcOM の溶解度が小さいから [AcOM]=

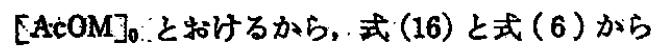

$$
\begin{aligned}
& k_{1, \mathrm{a}}=k_{7} K_{8}{ }^{1 / 2}[\mathrm{AcOM}]_{0}^{1 / 2} \\
& k_{3, \mathrm{a}}=k_{7} K_{3}^{1 / 2}
\end{aligned}
$$

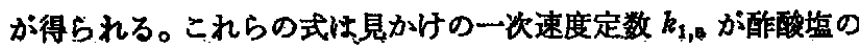
初灌度の $1 / 2$ 次比例することを示している。このことは図 3 の結 果と一致する。 $k_{1, \mathrm{a}}$ vs. [AcOM $]_{0}$ のブロットの頑きから $k_{\mathrm{g}, \mathrm{a}}\left(l^{1 / 2}\right.$.

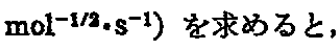

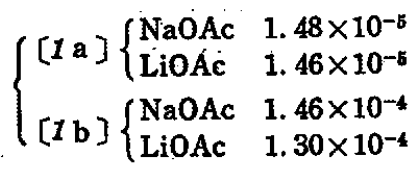

が得られた。 $\mathrm{Na}$ 塩す Li 塩すほぼ同じ值である。また, $[1 \mathrm{~b}]$ の 方が $[1 \mathrm{a}]$ より約 10 倍脱離速度がはやい。

\section{7 壦類効果}

$[1 \mathrm{a}],[1 \mathrm{~b}]$ とる $\mathrm{LiClO}_{4}$ の好果恃ない。すなわち, 異種了 シオンの効果ない。[1 a ] の場合, 明らか弱い共通陰イオン効 果が観測されているが, [1 b] の方は反応の增加が認められてい る。しかし, $k_{1, \mathrm{a}}$ vs. [Salt $]_{0}^{1 / 2}$ のプロット(図 5) は [Salt $]_{0}=$ 0の点を通らず反応低下 (四 5 の点線) が認められる。Winstein はコレステリルトシラートやブロシラートの加溶媒分解反沁でし れと同し傾向を認め，共通陰イオン効果によるものとしている20)。 本研究も同様に，共通陰イオン效果と考えてよい。最近の著者の 研究でエタノール・水 $(22: 1 \mathrm{v} / \mathrm{v})$ 中, $60^{\circ} \mathrm{C} て ゙[1]$ の醀酸によ る脱雄の場合，共通陰イオン効果は全〈認められなかった ${ }^{19)}$ 。 Cram は親電子置換反応でエタノール中は䋈密イオン対で起こり, ジメチルスルホキシド中は锅媒介在イオン対を経て起こることを 報告している21)。したがって，本研究の場合イオン対の立体モデ ルからす反応が起こりらるから共通陰イオン効果が観察されたと 考えてよい。

因 5 でるっとも特致的なことはアニオンの浱度が高いところで の $[1 \mathrm{~b}]$ の脱離速度の堌加である。 $\beta$-水素性 [5]の方が $[1]$ よりす活性（酸性）が高く，しかす，これと同し傾向がエタノー ル・水中の場合 ${ }^{19}$ も起こることから，これはアセタートアニオン が[5]のß-水素攻繋するためと考えてよい。緊密イオン対の 立体モデルを考学ると，[5a]はアセタートアニオンが $\beta$-水素の 近傍に位置するため，加えた塩妿ら生ずるるう1分子のアセター トアニオンが $[5 \mathrm{a}]$ の $\beta$-水素に近つくと対陰イオンとの立体障 害招よび電子的な反発のため起こらない。他方，[5b]ではアセ

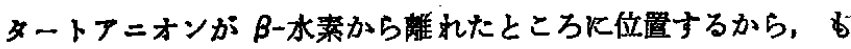
丂1分子のアセタートアニオン（塩の解離によって生じたすの）

20) S. Winstein, E. Clippinger, A.H. Fainberg, G.C. Robinson, J. Amer. Chem. Soc., 78, 328(1956).

21) D. J. Cram, A. Langemann, F. Hauck, ibid., 81, 5750 （1959）およびその一連の報告.
が $\beta$-水素に接近しても立体障害がないので脱睢が起こる。した がって，図 5 の反応速度の增加性次式によるるのと結論できる。 ここで， $k_{8}$ は 2 次速度定数である。

$$
[5 \mathrm{~b}]+\mathrm{AcO}^{-} \stackrel{k_{8}}{\longrightarrow}[2 \mathrm{~b}]+\mathrm{AcO}^{-}+\mathrm{AcOH}
$$

式（19）の機構について速度式をたてると,

$$
\begin{aligned}
& k_{2, \mathrm{a}}=k_{8} K_{\mathrm{8}}{ }^{1 / 2}[\mathrm{ACOM}]_{0}^{1 / 2} K_{1} \\
& k_{\mathrm{i}, \mathrm{a}}=k_{8} K_{\mathrm{s}}{ }^{1 / 2} K_{1}
\end{aligned}
$$

が得られる。 $k_{4, a}$ 注見かけの 2.5 次速度定数であり, 図 5 のプロ ットの傾きと図4のプロットの傎きの差である。 NaOAc, LiOAc の $k_{4, \mathrm{a}}$ を求めるとそれぞれ $2.3,1.6 \times 10^{-9} l^{3 / 2} \cdot \mathrm{mol}^{-3 / 2} \cdot \mathrm{s}^{-1}$ の值 が得られる。

\section{8 反庶速度比 $r$}

アセタートアニオンによる[1]の脱離反沁の速度比 $r$ は，

$$
r=\frac{k_{\mathrm{s}, \mathrm{a}}([1 \mathrm{a}])}{k_{\mathrm{s}, \mathrm{a}}([1 \mathrm{~b}])}=\frac{k_{7}([1 \mathrm{a}])}{k_{7}([1 \mathrm{~b}])}
$$

で示され，アセタートアニオンの[1]の $\beta$-水素の攻撃の容易さ の比といえる。眽酸ナトリウム，酢酸りチウムの速度比はそれそ れ0.10，0.11 といずれる1より小さいこのことは $11 \mathrm{~b}] の \beta-$ 水素の方が $[1 \mathrm{a}]$ よりす酸性 (活性) が高いことを示唆している。

カルポン酸による[1]の脱離の速度比 $r$ は1より大である。 寸なから, $[1 \mathrm{a}]$ の脱離速度の方が $[1 \mathrm{~b}]$ 上りもはやい。のこと はきわめて特徵的といえる。カルボン酸化よる脱離の速度比 $r$ は

$$
r=\frac{k_{2, \mathrm{a}}([1 \mathrm{a}])}{k_{2, \mathrm{a}}([1 \mathrm{~b}])}=\frac{K_{1}([1 \mathrm{a}])}{K_{1}([1 \mathrm{~b}])} \cdot \frac{k_{5}([1 \mathrm{a}])+K_{2}{ }^{\prime} k_{6}([1 \mathrm{a}])}{k_{5}([1 \mathrm{~b}])+K_{2}{ }^{\prime} k_{6}([1 \mathrm{~b}])}
$$

で示されるが，キナルジンとレピジンの水中の $p K_{a}$ 値はそれぞ れ 5.83，5.67 であるから $K_{1}([1 \mathrm{a}]) / K_{1}([1 \mathrm{~b}]) \sim 1.4$ である と考えられる22)。したがって，rの增城は

$$
\frac{k_{5}([1 \mathrm{a}])+K_{2}^{\prime} k_{6}([1 \mathrm{a}])}{k_{5}([1 \mathrm{~b}])+K_{2}^{\prime} k_{6}([1 \mathrm{~b}])}
$$

で決定されると考えてよい。

カルボン酸による脱離の速度比 $r$ の㑯向はイオン対の立体モデ ルからつぎのよらに説明できる。カルボキシラートアニオンとカ チオン $\mathrm{HN}^{+}$間の距離が長くなると $K_{2}^{\prime}$ が大きくなり〔6]の湦 度が高くなる。すなわち， $k_{5}$ 化対する $K_{2}{ }^{\prime} k_{6}$ の割合が大くな る。 [1 a ] の場合 $k_{5}>k_{8}$, つまり [5]加らの脱離の重みが大き く, $[1 \mathrm{~b}]$ の場合 $k_{6}>k_{5}$ であるから〔6]からの脱離の割合が大 きい。したがって，式（24）の分子は小さくなり，分母が大きく

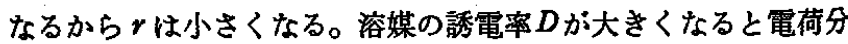
離が起こり $\mathrm{RCO}_{2}$ - と $\mathrm{HN}^{+}$間の距離が長くなるからては小さく なる。これは，因6の結果と一致する。カルボン酸の酸性が強く なると $\mathrm{RCO}_{2}$ - の負の電荷は $\mathrm{R}$ の電子吸引効果により小さくなり, $\mathrm{RCO}_{2}$ - と $\mathrm{HN}^{+}$間の距離が長くなって， 表 5 の結果と一致する。溶媒の電子供与度が大きくなると， $K_{2}^{\prime}$ が大きくなり[6]からの脱離の割合が大きくなっでは小さく

22）エタノール中， $\mathrm{BF}_{3}$ 触媒の場合，r=1.4であることから， このことは正しいと考竞られる。な报， $\mathrm{BF}_{8}$ 触媒の場合は

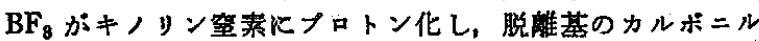
酸萃が $\beta$-水素を攻撃する $\mathrm{E}_{\imath}$ 機樓で進む $\left(k_{\mathrm{H}} / k_{\mathrm{D}}=2.2\right)$. 末発表データ. 
なる。これは図 7 の結果と一致する。

反応比 $r$ と誘電率との相関性（図 6) をみると、ジオキサンが 一群からはずれている。たとえば,トルエン中では $\boldsymbol{2}$ 20015) で あるのに対してジオキサンは $r=11.5$ と小さい。これは，電子 供与度が $\Delta \nu_{D}=77 \mathrm{~cm}^{-1}$ と大きいためである。他方, 電子供与度 との相関性（図 7) をみると，ジオキサンは $\Delta \nu_{\mathrm{D}}$ の值から期待 されるよりも大きな値である。これは，ジオキサンの誘電率が低 い( $D=2.21)$ ためである。 $k_{2, \mathrm{a}}$ がDと $\Delta \nu_{\mathrm{D}}$ に関自しているから， rるまた $D$ と $\Delta \nu_{\mathrm{D}}$ の関数であり，一つの因子に対してブロット をとるためずれるすのと考えられる。ジオキサンは第四級アンモ こウム塩が存在するとボート型からイス型への互変異性が起こる ことが知られている29)。本研究の場合, 生成する反応種 [5] は 第四級アミンであるが，それ自体が反応基筫であるから［8]の 形でジオキサンが配位して溶媒介在イオン対を生成すると考元ら れる。

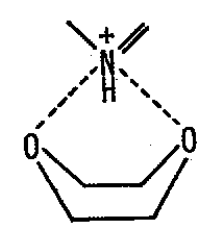

[8]

\section{9 屁移状龍}

醒酸エチル中， $50^{\circ} \mathrm{C}$ に括けるカルボン酸による[1 a ] の脱離 の $\beta$-水素同位体効果 $\left(k_{\mathrm{H}} / k_{\mathrm{D}}\right)$ の結果恃表 6 に示すと括りである。 $k_{\mathrm{H}} / k_{\mathrm{D}}>1$ であるから $\beta$-水素が脱離する段階, すなわら，カルボ キシラートアニオンが $\beta$-水素を攻撃する段階が律速である。 $k_{\mathrm{H}} /$ $k_{\mathrm{D}}$ の値は触媒が醀酸からトリクロ口醀酸へと変わるにつれて, モノクロ口䣫酸まで増加し，ついには隇少する。すなわち， $\beta$-水 素を攻撉する篮基, カルボキシラートアニオンの塩基度がモノク ロロアセタートよりも強くてる弱くても少さい值になる。このこ とは，攻慗塩基がモノクロロアセタートのとき [1]の脱離の僄 䔟状態が理想型であり，アセタートアニオンになると近 E $1 \mathrm{cB}$ 型に移行し、トリクロロアセタートアニオンになると近 $\mathrm{E} 1$ 型に 移行することを示す。また， $k_{\mathrm{H}} / k_{\mathrm{D}}$ の值が $\beta$-水素を攻撃するカ ルボキシラートアニオンの変化ととるに異なった值を示すことは ブロトン化・E 1 型の機檴 [9] やプロトン化・E $i$ 型の機構 [10] は否定される。

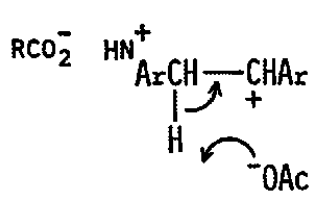

[9]

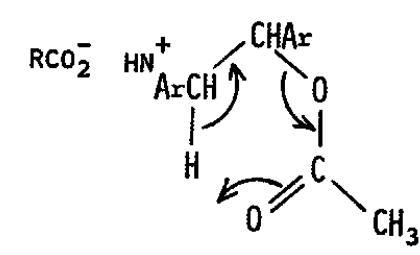

[10]
23）戸倉仁一郎, “溶媒和”, 化学モノグラフ 24, 化学同人 (1972)p.61.

\section{5 結}

\section{䤅}

1-(p-ニトロフェニル)-2-(2-および 4-キノリル)エチルニアセ タート（[1 a ] 怙よび [1 b ]）からカルボン酸触媒によってそれ ぞれ trans-2-拉よび 4-(p-ニトロスキリル)キノリン（[2a よび [2 b ] ) を生ずる脱離反応は式（8）の機構，すなわら，カ ルボン酸のキノリン窒素へのプロトン化，溶媒の作用によりそれ ぞれ㗨密イオン対 [5]於よび溶媒介在イオン対 [6]を生じ, これらの対陰イオンがキのおのの $\beta$-水素を律速的に攻慗して起 こる。ここで，この反席は特殊酸・一般塩基（速度論的には一般 酸）触媒で起こる。

プロトン化によって生ずるイオン対からの反応性は，対除イオ ソのカルボキシラートアニオンと $\boldsymbol{\beta}$-水素間の距離が大きく左右 する。[5a]の場合はカルボキシラートアニオンが $\beta$-水素の近

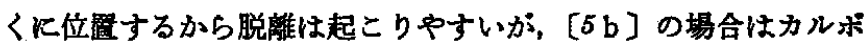
キシラートアニオンは $\beta$-水素から離れて存在するため反応速度 は遅い。さらに，アニオンを添加すると[5 b ] の揚合は立体障害 がないため反応が促進される(4.7)。しかし，式（13）のモデル で示したように，溶媒が [5]に作用して溶媒介在イオン対 [6] になると事情が異なる。[1 a ] の場合はカルボキシラートアニオ ンと $\beta$-水素間の距離は $[6 \mathrm{a}]>[5 \mathrm{a}]$ であるから速度が低下す る。 $[1 \mathrm{~b}]$ の場合は，[6 b $]<[5 \mathrm{~b}]$ となり反㐫が起こりやすく なる。また, 溶媒介在イオン対 [6]の生成に関しては, カルボ キシラートアニオン $\mathrm{RCO}_{2}^{-}$と $\mathrm{HN}^{+}$間の距離 (Coulomb 引力, すなわち，溶媒の誘電率と $\mathrm{RCO}_{2}^{-}$の電荷）と; $\mathrm{HN}^{+}$を攻撃する 溶媒の電子供与度 (求核性) が重要となる。反态は溶媒の極珄が 低い場合（たとえば，アニソール中）は〔5]加の脱離が主で あり，極性が高くなるにつれて〔6]の重みが大きくなる。本研 究の場合，一部溶媒介在イオン対 [6]を経ることがわかったが， たとえば水溶液中で行なえば反応は遊離イオンから起こるすのと 考えられる。

脱離の暧移状態は攻撃する塩基の強さによって巽なる。すなわ ち， $\boldsymbol{\beta}$-水素を攻撃するカルボキシラートアニオンの塩基度が強く なると，遷移状態は近 E 1 型から近 $\mathrm{E} 1 \mathrm{cB}$ 型に移行する。これ は興味ある結果である。エタノール中やトルェン中でる同様の傾 向が認められることから ${ }^{24)}$ ，これは溶媒介在イオン対 [6]の影 䁷によるものではない。[1 b $]$ の脱離の遷移状熊, 溶媒, 温度の 変化による遷移状態の変化については現在検討中である。

本研究はイオン対の立体モデルを仮定して実験結果を定性的に 説明するに成功したが，定量的には满足するるのとはいえない。 それは，たとえば緊密イオン対 [5]と溶媒介在イオン対 [6]の 濃度（あるいは，その存在の割合）がわからないことと，カルボ キシラートアニオンの正確な位置がかからないことに起因する。

本研究は名古屋大学工学部応用化学教室で行なかれた。

(1973 年 10 月, 中部化学関係学協会支部建合秋育大会一般研 究発表会(一部)発表)

24）平田博文, 福住一雄, 未発表データ. 


\title{
Carboxylic Acid Catalyzed Elimination Reactions of 1-(p-Nitrophenyl)- 2-(2- and 4-quinolyl)ethyl Acetates in Aprotic Solvents \\ _- Solvent Effect, Rate Ratio, Salt Effect and Kinetic Isotope Effect-
}

\author{
Hirohumi Hirata*, Hiroshi Tanaka** and Kazuo Fukuzumi** \\ * National Chemical Laboratory for Industry ; Honmachi, \\ Shibuya-ku, Tokyo 151 Japan \\ ** Department of Applied Chemistry, Faculty of Engineering, \\ Nagoya University ; Chikusa-ku, Nagoya-shi 464 Japan
}

Elimination reactions of acetic acid from 1-( $p$-nitrophenyl)-2-(2- and 4-quinolyl)ethyl acetates $([1 \mathrm{a}]$ and $[1 \mathrm{~b}])$ to give trans-2- and $4-(p$-nitrostyryl) quinolines ([2a] and $[2 \mathrm{~b}]$ ), respectively, have been studied kinetically in some aprotic solvents. The above eliminations were catalyzed by some carboxylic acids and acetate anion (as $\mathrm{AcOM} ; \mathrm{M}=\mathrm{Na}, \mathrm{Li}$ ). The catalytic power was in the order: acetic acid>acetate anion, and $\mathrm{Cl}_{8} \mathrm{CCO}_{2} \mathrm{H}>\mathrm{Cl}_{2} \mathrm{CHCO}_{2} \mathrm{H}>$ $\mathrm{ClCH}_{2} \mathrm{CO}_{2} \mathrm{H}>\mathrm{PhCO}_{2} \mathrm{H}>\mathrm{CH}_{3} \mathrm{CO}_{2} \mathrm{H}$. The rate for the carboxylic acid catalyzed elimination was expressed as $v=k\left[\mathrm{RCO}_{3} \mathrm{H}\right]_{0}[$ Substrate], which suggests a general acid catalysis in the over-all reaction. The rate for $[1 \mathrm{a}]$ was correlated with the electron donability $\Delta \nu_{\mathrm{D}}\left(\mathrm{cm}^{-1}\right)$ of solvent rather than the solvent dielectric constant $D$, however, that for $[1 \mathrm{~b}]$ showed different pictures. The effect of a common anion was observed for both substrates, and an increase in rate was observed for [ $[1 \mathrm{~b}]$ (for the acetic acid catalyzed elimination in dimethyl sulphoxide-water $(22: 1, \mathrm{v} / \mathrm{v})$ at $\left.90^{\circ} \mathrm{C}\right)$. The rate ratio $r=k([1 \mathrm{a}]) / k([1 \mathrm{~b}])$ was smaller than unity (i.e., the rate of $[1 \mathrm{~b}]$ is higher than that of $[1 \mathrm{a}])$ for the acetate anion (AcOM) catalyzed elimination, however, was larger than unity for the carboxylic acid catalyzed eliminations. The ratio $r$ for the carboxylic acid catalyzed elimination decrease with increasing the acidity of carboxylic acids, the solvent dielectric constant $D$ and the electron donability $\Delta \nu_{\mathrm{D}}$ of solvent. The kinetic isotope effect, $k_{\mathrm{H}} / k_{\mathrm{D}}$, was measured for the carboxylic acid catalyzed elimination of $[1 \mathrm{a}]$ in ethyl acetate at $50^{\circ} \mathrm{C}$. The value of $k_{\mathrm{H}} / k_{\mathrm{D}}$ was larger than unity, which suggests a rate-determining elimination of $\beta$-hydrogen. The value of $k_{\mathrm{H}} / k_{\mathrm{D}}$ increases at first, thruogh a maximum, and then decreases with increasing the basicity of the attacking base on the $\beta$-hydrogen. This is consistent with a transition state varying from E 1-like to E $1 \mathrm{cB}$-like.

From the above observations, a most possible mechanism involving a protonation by carboxylic acid on the nitrogen atom of [1] to give a tight ion pair [5] and a solvent separated one [6] resulting from an interaction between the solvent molecule(s) and [5], and the ratedetermining attack of carboxylate anion on the $\beta$-hydrogen within [5] and [6] to give trans-olefin [ 2 ] is proposed and discussed tentatively by assuming the steric models of the ion pairs. 